\title{
Stable Respiratory Activity Requires Both P/Q-Type and N-Type Voltage-Gated Calcium Channels
}

\author{
Henner Koch, ${ }^{1,2,5 *}$ Sebastien Zanella, ${ }^{1,2 *}$ Gina E. Elsen, ${ }^{1}$ Lincoln Smith, ${ }^{3}$ Atsushi Doi, ${ }^{1,2}$ Alfredo J. Garcia III, ${ }^{1,2}$ \\ Aguan D. Wei, ${ }^{1,2}$ Randy Xun, ${ }^{1}$ Sarah Kirsch, ${ }^{1}$ Christopher M. Gomez, ${ }^{4}$ Robert F. Hevner, ${ }^{1,2}$ and Jan-Marino Ramirez ${ }^{1,2}$ \\ ${ }^{1}$ Center for Integrative Brain Research, Seattle Children's Research Institute, Seattle, Washington 98101, 2Department of Neurological Surgery, University of \\ Washington, Seattle, Washington 98104, ${ }^{3}$ Center for Lung Biology, Department of Pediatrics, University of Washington, Seattle, Washington 98105, \\ ${ }^{4}$ Department of Neurology, University of Chicago Medical Center, Chicago, Illinois 60637, and ${ }^{5}$ Department of Neurology and Epileptology, Hertie-Institute \\ for Clinical Brain Research, University of Tübingen, D-72076 Tübingen, Germany
}

P/Q-type voltage-gated calcium channels $\left(\mathrm{Ca}_{\mathrm{v}} 2.1\right)$ play critical presynaptic and postsynaptic roles throughout the nervous system and have been implicated in a variety of neurological disorders. Here we report that mice with a genetic ablation of the Ca 2.1 pore-forming $\alpha_{1 \mathrm{~A}}$ subunit $\left(\alpha_{1 \mathrm{~A}}{ }^{-I-}\right)$ encoded by CACNAla (Jun et al., 1999) suffer during postnatal development from increasing breathing disturbances that lead ultimately to death. Breathing abnormalities include decreased minute ventilation and a specific loss of sighs, which was associated with lung atelectasis. Similar respiratory alterations were preserved in the isolated in vitro brainstem slice preparation containing the pre-Bötzinger complex. The loss of $\mathrm{Ca}_{\mathrm{v}} 2.1$ was associated with an alteration in the functional dependency on $\mathrm{N}$-type calcium channels $\left(\mathrm{Ca}_{\mathrm{v}} 2.2\right)$. Blocking $\mathrm{N}$-type calcium channels with conotoxin GVIA had only minor effects on respiratory activity in slices from control (CT) littermates, but abolished respiratory activity in all slices from $\alpha_{1 \mathrm{~A}}{ }^{-/-}$mice. The amplitude of evoked EPSPs was smaller in inspiratory neurons from $\alpha_{1 \mathrm{~A}}{ }^{-1-}$ mice compared with CTs. Conotoxin GVIA abolished all EPSPs in inspiratory neurons from $\alpha_{1 \mathrm{~A}}{ }^{-1-}$ mice, while the EPSP amplitude was reduced by only $30 \%$ in CT mice. Moreover, neuromodulation was significantly altered as muscarine abolished respiratory network activity in $\alpha_{1 \mathrm{~A}}{ }^{-1-}$ mice but not in CT mice. We conclude that excitatory synaptic transmission dependent on $\mathrm{N}$-type and $\mathrm{P} / \mathrm{Q}$-type calcium channels is required for stable breathing and sighing. In the absence of $\mathrm{P} / \mathrm{Q}$-type calcium channels, breathing, sighing, and neuromodulation are severely compromised, leading to early mortality.

\section{Introduction}

During postnatal development, ion-channel and receptor subtypes exhibit complex expression profiles that differ in different brain regions (Möhler, 2006; Hall and Ghosh, 2008; Hirtz et al., 2011). These expression profiles have important functional consequences that depend upon metabolic, modulatory, disease, and activity states (Peña et al., 2004; Doi and Ramirez, 2008; Jansen et al., 2010; Moreno and Ribera, 2010; De Marco García et al., 2011; Tse et al., 2011). Ion channels that are redundant in one state may become critical at another state (Peña et al., 2004). Thus, even apparently simple monogenic disorders reveal complex phenotypes. For example, patients with the same sodium channelsubunit mutation exhibit broad ranges of seizure severity and onset (Gourfinkel-An et al., 2004; Glasscock et al., 2007). Similarly complex are the consequences of mutations in $\mathrm{P} / \mathrm{Q}$-type

Received Dec. 21, 2011; revised Nov. 27, 2012; accepted Dec. 1, 2012.

Author contributions: H.K., S.Z., C.M.G., R.F.H., and J.-M.R. designed research; H.K., S.Z., G.E.E., L.S., A.D., A.J.G., R.X., and S.K. performed research; H.K., S.Z., G.E.E., and L.S. analyzed data; H.K., S.Z., A.D.W., and J.-M.R. wrote the paper.

This work was supported by the following grants from the National Institutes of Health: HL107084-01 and P01HL090544.

*H.K. and S.Z. contributed equally to this work.

Correspondence should be addressed to Dr. Jan-Marino Ramirez, Center for Integrative Brain Research, Seattle Children's Research Institute, 1900 9th Avenue, Seattle, WA 98101. E-mail: nino1@uw.edu.

DOI:10.1523/JNEUROSCI.6390-11.2013

Copyright $\odot 2013$ the authors $\quad 0270-6474 / 13 / 333633-13 \$ 15.00 / 0$ voltage-gated calcium channels $\left(\mathrm{Ca}_{\mathrm{v}} 2.1\right)$, which can result in migraine, epilepsy, and ataxia (Ophoff et al., 1996; Zhuchenko et al., 1997). Mouse models with a Cacnala mutation reveal different phenotypes at different developmental stages (Zhang et al., 2004; Neychev et al., 2008; Pietrobon, 2010; Mark et al., 2011).

Here, we studied the functional consequences of a genetic ablation of P/Q-type voltage-gated calcium channels $\left(\mathrm{Ca}_{\mathrm{v}} 2.1\right)$ (Jun et al., 1999) on the respiratory network. This network is functionally well characterized and $\mathrm{Ca}_{\mathrm{v}} 2.1$ differentially contributes to different forms of respiratory patterns (Lieske and Ramirez, 2006). Located within the ventrolateral medulla, a kernel of several hundred neurons (Hayes et al., 2012) forms the pre-Bötzinger Complex (preBötC), which is essential for breathing (Smith et al., 1991; Ramirez et al., 1998b; Wenninger et al., 2004; Tan et al., 2008) and is sufficient in isolation to generate neuronal activity patterns resembling eupneic activity (normal respiratory activity) and sigh and gasping activity (Lieske et al., 2000; Ruangkittisakul et al., 2008). In fact, the same pre-BötC neurons can be active during eupnea, gasps, and sighs.

Pharmacological experiments suggest that sighs and eupneic output are critically dependent on calcium currents carried by P/Q-type channels (Lieske and Ramirez, 2006). P/Q-type channels mediate synaptic transmission at the presynaptic terminal (Turner et al., 1992; Wheeler et al., 1994; Dunlap et al., 1995) and these channels can be specifically blocked by $\omega$-agatoxin IVA (Mintz et al., 1992; Turner et al., 1992). This approach has been 
used to study the role of these channels in the cerebellum (Mintz, 1994), hippocampus (Wheeler et al., 1994), and brainstem (Lieske and Ramirez, 2006). In slices containing the pre-BötC, acute pharmacological blockade of P/Q-type calcium channels specifically abolishes sighs at concentrations that did not affect fictive eupneic output. Here we show that the majority of mice carrying genetic deletion of the $\mathrm{Ca}_{\mathrm{v}} 2.1$ (CACNA1a) gene encoding the $\alpha_{1 \mathrm{~A}}$-subunit of the P/Q-type calcium channel $\left(\alpha_{1 \mathrm{~A}}{ }^{-1-}\right.$; $\mathrm{KO})$ fail to generate sighs in vivo and in vitro. However, the fact that in rare cases, individual $\mathrm{KO}$ mice were capable of generating sighs indicates that $\mathrm{P} / \mathrm{Q}$-type calcium channels are not essential for their generation. Thus, the $\mathrm{N}$-type calcium channel alone can support eupneic and sigh activity, but these activities are severely compromised and show an altered modulatory response to muscarine. Our study suggests that the combined reliance on $\mathrm{N}$-type and $\mathrm{P} / \mathrm{Q}$-type calcium channels protects the animal against the loss of the P/Q-type channel during the first postnatal week, but the N-type channel alone becomes increasingly insufficient to promote stable breathing during the second week, culminating in early morbidity.

\section{Materials and Methods}

All animal experiments were performed with the approval of the Institutional Animal Care and Use Committee of the Seattle Children's Research Institute (Protocol \#13404). Mice were maintained with rodent diet and water available ad libitum in a vivarium with a $12 \mathrm{~h}$ light-dark cycle at $22^{\circ} \mathrm{C}$.

\section{Genotyping}

Mouse tails were dissected and digested in DirectPCR Lysis Reagent (tail) (Viagen Biotech) and proteinase $\mathrm{K}(1 \mu \mathrm{g} / \mu \mathrm{l})$. The CACNAla gene was amplified from the lysate with primer pairs NeoU1;S (5'-CGT TCC TTG CGC AGC TGT GCT C-3' ) and mCACNA1a,ex5;AS (5'-GGG ATC ATC GCC TTC ATG ATT GAC TTC AGG ACG ACT-3'); and mCACNA1a,in4;AS (5' -CTG ACC CTA ATC CAA CTA TTC AGC CAT CCC GAG TCT- $3^{\prime}$ ) and mCACNAla,in3,EcoRI;S (5'-ACA GAA GGA ATT CTA TGA GTT CAG TAA CAG CCT GGG CTA-3') to determine deletional mutant (size, $1500 \mathrm{bp}$ ) and wild-type (size, $930 \mathrm{bp}$ ) copies of CACNAla, respectively.

Phenotype of $\alpha_{1 A}{ }^{-/-}$mice

As described before, homozygous $\alpha_{1 \mathrm{~A}}$-null mutant mice (KO) were initially viable and showed few symptoms in the first postnatal week, but developed a more severe phenotype entering the second postnatal week. All KO mice became severely ataxic, had a significantly lower body weight, and progressively lost the ability to move before their death between postnatal day (P) 20 and P30 (Jun et al., 1999). Heterozygote littermates of $\mathrm{KO}$ mice showed no apparent abnormalities in all analyzed parameters and were fertile. Therefore, heterozygote mice were grouped with wild-type littermates in one single group [control mice (CT)] for further analysis.

\section{In vivo whole-body plethysmography}

The breathing of unanesthetized and unrestrained mice (males and females) was assessed using a constant flow whole-body plethysmograph (Buxco Research System) during the first (P5-P6) and the second (P11P12) postnatal weeks. Each animal was acclimatized in a $200 \mathrm{ml}$ chamber maintained at $25^{\circ} \mathrm{C}$ and continuously ventilated with air $(300 \mathrm{ml} / \mathrm{min})$ for at least $10 \mathrm{~min}$ before ventilation measurements were obtained. Measurements of rectal temperature revealed no differences between CT and $\mathrm{KO}$ mice. Changes in pressure caused by inspiration and expiration were measured, using a differential pressure transducer (Buxco Research System), and then amplified and digitally recorded. We characterized the respiratory frequency [Rf; in cycle per $\left.\min \left(\mathrm{c} . \mathrm{min}^{-1}\right)\right]$, the tidal volume (VT, $\mu \mathrm{l})$ normalized as the ratio VT divided by the body weight $(\mathrm{VT} / \mathrm{B}$, $\left.\mu \mathrm{l} . \mathrm{g}^{-1}\right)$, the minute ventilation $\left(\mathrm{Ve}, \mathrm{ml} \cdot \mathrm{g}^{-1} \cdot \mathrm{min}^{-1}\right)$, and the sigh frequency (sighs . $\min ^{-1}$ ) during a period of quiet breathing of few minutes. For statistical analysis, differences were considered significant when $p<0.05$. The significance of difference between genotypes (KO vs $\mathrm{CT}$ ) was determined by Student's $t$ test.

In vivo recordings from anesthetized freely breathing mice

All male and female CT and KO mice (P16-P21) were anesthetized with urethane $(1.5 \mathrm{~g} / \mathrm{kg})$ before the recordings. The mice were subsequently placed in a supine position, and the head was fixed with a stereotaxic apparatus. Gas mixtures were supplied to the mice by a plastic nose cone placed over the mouth. The mice were initially kept on room air without ventilation to obtain stable breathing recordings, followed by a mixture of $95 \% \mathrm{O}_{2}$ and $5 \% \mathrm{CO}_{2}$ for $10 \mathrm{~min}$, before they were exposed to severe hypoxia ( $95 \% \mathrm{~N}_{2}$ and $5 \% \mathrm{CO}_{2}$ ). To compare the hypoxic responses, $\mathrm{KO}$ and CT mice were exposed to severe hypoxia for 1, 1.5, and $3.5 \mathrm{~min}$. Electromyography recordings of the intercostal muscles were recorded with a Teflon-covered Ag bipolar electrode. The skin over the abdominal and intercostal area on the right side was partially removed, and the bipolar electrode was placed on the surface of the intercostal muscles. Signals were AC amplified and bandpass filtered $(8 \mathrm{~Hz}-3 \mathrm{kHz})$.

\section{Preparation of brainstem slices and population recordings}

Transverse brainstem slice (550-600 $\mu \mathrm{m}$ thick) preparations containing the preBötC were obtained from 5-14-d-old mice (null mutants and hemizygous and wild-type littermates) as described in detail previously (Ramirez et al., 1998a). The slices were transferred into a recording chamber and superfused with 100-200 ml of artificial CSF (aCSF) containing (in mM) $118 \mathrm{NaCl}, 3 \mathrm{KCl}, 1.5 \mathrm{CaCl}_{2}, 1 \mathrm{MgCl}_{2}, 25 \mathrm{NaHCO}_{3}, 1$ $\mathrm{NaH}_{2} \mathrm{PO}_{4}$, and 30 D-glucose, and equilibrated with carbogen $(95 \%$ $\left.\mathrm{O}_{2}-5 \% \mathrm{CO}_{2}, \mathrm{pH} 7.4\right)$ in a recycling system. Temperature was maintained at $30 \pm 1^{\circ} \mathrm{C}$. After $20 \mathrm{~min}$, the concentration of $\mathrm{KCl}$ was raised to $8 \mathrm{~mm}$ to obtain spontaneously rhythmic population activity from the ventral respiratory group (VRG). Only one set of experiments was performed on an individual slice, and only one rhythmic slice could be obtained from any individual mouse. For experiments with $\mathrm{Ca}^{2+}$ antagonists, the bath volume was reduced to $50 \mathrm{ml}$ and the activity recorded for 10-20 min before bath application of the drugs. Population recordings were obtained from the caudal surface of the slices at the region of the VRG with glass electrodes $(<1 \mathrm{M} \Omega)$ to achieve multiunit recordings. The activity was amplified $(10,000 \times)$ and filtered (bandpass, $0.3-5 \mathrm{kHz})$ using a differential AC amplifier (Model 1700, A-M Systems) and then rectified and integrated (time constant, $50 \mathrm{~ms}$ ) using an analog dual channel integrator (JFIE 1620A, James Franck Institute Electronics Laboratory, University of Chicago). Data were digitized with an Axon Digidata A/D converter $(1320,1440 \mathrm{~A})$ and PClamp software (version 9.2 and 10.0; Molecular Devices) and stored on PCs for further analysis. We measured the fictive inspiratory burst frequency, amplitude, and the sigh frequency during control conditions and during drug application or anoxia $(<1 \%$ $\mathrm{O}_{2}$ ). All drugs were supplied from Sigma-Aldrich or Tocris Bioscience. $\omega$-Agatoxin IVA was purchased from Alomone.

\section{Intracellular recordings of preBötC neurons}

Whole-cell patch-clamp recordings were obtained from inspiratory neurons of the preBötC using the blind patch technique. For the recordings, patch electrodes were manufactured from borosilicate glass and had a resistance of 3-8 M $\Omega$. They were filled with solution containing (in mM) the following: $140 \mathrm{~K}$-gluconic acid, $1 \mathrm{CaCl}_{2}, 10 \mathrm{EGTA}, 2 \mathrm{MgCl}_{2}, 4$ $\mathrm{Na}_{2} \mathrm{ATP}, 10$ HEPES. Intracellular recordings were performed in currentclamp conditions using BVC-700A (Dagan) and Multiclamp 700B (Molecular Devices) amplifiers. In a subset of experiments, the intracellular solution contained biocytin $(4.5 \mathrm{mg} / \mathrm{ml})$ to identify the morphology and location of the recorded cells (see Fig. 7A). Throughout the study, we characterized only one neuron per slice and per animal.

\section{Evoked EPSPs induced by electrical stimulation of the contralateral preBötC}

After whole-cell configurations from inspiratory neurons were established, the aCSF superfusing the slice was replaced with aCSF with $3 \mathrm{~mm}$ potassium to silence the network and hyperpolarize the cells to eliminate spontaneous firing. EPSPs were evoked by a brief electric stimulation pulse of the contralateral preBötC $(1 \mathrm{~ms} ; 10-100 \mu \mathrm{A})$ at a frequency of $0.1 \mathrm{~Hz}$ delivered through the glass surface electrode used prior to record 
the population activity. Before drug application, at least 30 consecutive EPSPs were recorded to obtain a stable baseline. The amplitude of the evoked EPSPs was measured as the difference between the peak voltage deflection within $20 \mathrm{~ms}$ following the stimulation artifact and the resting potential $1 \mathrm{~s}$ after the stimulation. Statistical significance between the groups was assessed with an unpaired Student's $t$ test (Prism 4, GraphPad Software).

\section{Lung histology}

Twelve-day-old mice were killed, their tracheas dissected and cannulated with a 24 gauge catheter (Surflo IV, Terumo), and the cannulas secured with 2.0 silk ties. A median sternostomy was performed and the diaphragms were removed. Then the left kidney was dissected and the left renal artery was cut. The lungs were inflated to $20 \mathrm{~cm} \mathrm{H}_{2} \mathrm{O}$ with medical air and the lungs were fixed by intravascular perfusion by injection of $4 \%$ paraformaldehyde into the right ventricle at $<18 \mathrm{~cm} \mathrm{H}_{2} \mathrm{O}$ until the $4 \%$ paraformaldehyde was seen to leak into the peritoneal cavity from the left renal artery. The trachea was ligated with 2.0 silk and the entire animal was placed in $4 \%$ paraformaldehyde for $24 \mathrm{~h}$. After $24 \mathrm{~h}$ in paraformaldehyde, the heart-lung block was removed and placed into $70 \%$ alcohol. Then the lungs were embedded in paraffin and lung sections were prepared and stained with hematoxylin and eosin for light microscopy.

Tissue preparation and histological analysis of the preBötC area Histology was performed on transverse brainstem slices (550-600 $\mu \mathrm{m}$ thick) containing the preBötC obtained from 5-14-d-old mice (KOs and littermates) as previously described in Materials and Methods section. Slices were fixed in cold buffered $4 \%$ paraformaldehyde in $1 \times$ PBS, frozen in optimum cutting temperature compound (OCT, VWR International), cryostat sectioned at $16 \mu \mathrm{m}$ [for immunofluorescence and in situ hybridization (ISH)], and mounted on Superfrost Plus slides (Thermo Fisher Scientific). Slide-mounted sections were stored at $-80^{\circ} \mathrm{C}$ until needed. For Nissl staining, $16 \mu \mathrm{m}$ sections were stained with $0.5 \%$ cresyl violet, as previously described (Hevner et al., 2001).

$I S H$. Nonradioactive ISH, using digoxigenin-labeled Vglut2 RNA antisense probe (Roche Diagnostics), was done with $16 \mu \mathrm{m}$ slide-mounted sections as previously described (Bedogni et al., 2010). Vglut2 probe was synthesized from the Vglut2 cDNA spanning $\sim 1200$ bp (2527 bp position to 3728 bp position of the published Vglut2 PubMed clone BC038375) subcloned into pBSIISK(+) at the HindIII and NotI restriction sites. Antisense ISH results were replicated on 3-5 pups from at least two different litters for each age group examined.

Immunohistochemistry. Immunohistochemistry was done as previously described (Bedogni et al., 2010). Briefly, for immunofluorescence, cryosections were air dried at room temperature for $15 \mathrm{~min}$, washed three times in PBS, blocked for $1 \mathrm{~h}$ at room temperature with $10 \%$ goat serum in PBS containing $0.1 \%$ Triton $\mathrm{X}-100$ and $0.2 \%$ bovine serum albumin (blocking solution) and then incubated overnight at $4^{\circ} \mathrm{C}$ with primary antibodies appropriately diluted (see below) in blocking solution. Species-specific fluorescent-tagged secondary antibodies (Invitrogen/ Life Technologies; Alexa-Fluor-488 and Fluor-546 at 1:400 dilution in blocking solution) were applied for $2 \mathrm{~h}$ at room temperature, and sections were counterstained with the nuclear label DAPI (Invitrogen/Life Technologies) and coverslipped with microscope cover glass (Thermo Fisher Scientific) using Fluormount-G (Southern Biotech). The following primary antibodies were used at the dilutions indicated: rabbit polyclonal anti-Nk1R (Advanced Targeting Systems; 1:500), anti-activated caspase-3 (Cell Signaling Technologies; 1:500).

Image analysis and cell counting. Images of antigens of interest at high magnification were obtained using a Zeiss LSM 710 confocal microscope (40× objective; 405, 488, and $543 \mathrm{~nm}$ laser lines). Mosaic images at low magnification were obtained using a Zeiss ApoTome ( $10 \times$ objective). For Vglut2 (Slc17a6) mRNA+ cells within the preBötC area, counts were made from CT and KO littermates at comparable levels, approximately every fifth slide-mounted $16 \mu \mathrm{m}$ section. Total Vglut2+ cell numbers/ section within individual preBötC were assessed from adjacent sections stained with NK1R to determine the exact location of preBötC. The total number of cells within preBötC was counted as DAPI+ cells within a $40 \times$ microscopic field encompassing the preBötC area (assessed from double immunofluorescence staining with NK1R). For all cell counts, 3-4 KOs and controls at both postnatal stages were used and data are presented as mean \pm SEM. Statistical analysis was conducted using GraphPad Prism 5 software. To assess significance between controls and KOs at each postnatal age group, we used unpaired, two-tailed, Student's $t$ test.

\section{Statistical analysis}

Numerical data are presented as the mean \pm SEM. $N$ values represent the number of mice or slices or neurons from which the quantification was conducted. Otherwise stated differences between two groups were determined by the unpaired Student's $t$ test. Differences between $>2$ groups were determined using one-way ANOVA followed by multiplecomparisons testing (Tukey's comparison) using GraphPad Prism 5. All differences were considered significant at $p<0.05$.

\section{Results}

\section{In vivo recording of breathing activity in unrestrained}

\section{$\alpha_{1 \mathrm{~A}}{ }^{-/-}$mice under control conditions}

Breathing activity of unanesthetized and unrestrained $\alpha_{1 \mathrm{~A}}{ }^{-/-}$ (KO) mice was assessed and compared with their CT littermates during the first (P5-P6; $n=12 \mathrm{CT} ; n=6 \mathrm{KO}$ ) and second (P11-P12; $n=16 \mathrm{CT} ; n=11 \mathrm{KO})$ postnatal weeks using wholebody plethysmography (Fig. $1 A, B$ ). At these stages, KO mice had a lower weight than CT littermates (Fig. 1C,D; unpaired $t$ test, $t_{(16)}=3.481, p<0.01$ and $t_{(25)}=4.399, p<0.001$ for first and second postnatal weeks, respectively). During the first postnatal week, $\mathrm{KO}$ mice showed a significant lower Rf compared with CT mice $\left(122 \pm 15\right.$ and $179 \pm 13 \mathrm{c} . \mathrm{min}^{-1}$ for $\mathrm{KO}$ and CT, respectively; unpaired $t$ test, $t_{(16)}=2.636, p=0.018$ ), while the VT/B was not affected $\left(13.2 \pm 2.2\right.$ and $13.8 \pm 1.2 \mu \mathrm{l.g} \mathrm{g}^{-1}$ for $\mathrm{KO}$ and $\mathrm{CT}$, respectively; $p=0.79$ ). Thus the Ve tended to be lower for $\mathrm{KO}$ mice $\left(1.8 \pm 0.4 \mathrm{ml} . \mathrm{min}^{-1} \cdot \mathrm{g}^{-1}\right)$ compared with CT mice $\left(2.6 \pm 0.4 \mathrm{ml} \cdot \mathrm{min}^{-1} \cdot \mathrm{g}^{-1}\right)$ but was not significantly altered at this stage ( $p=0.19$; Fig. $1 C$ ). By contrast, during the second postnatal week (Fig. 1D), Rf, VT/B, and Ve were significantly lower in KO mice (Rf, $145 \pm 19 \mathrm{c} . \mathrm{min}^{-1}$; VT/B, $12.8 \pm 2.0 \mu \mathrm{l.g}{ }^{-1}$; Ve, $2.2 \pm$ $0.6 \mathrm{ml} . \mathrm{min}^{-1} \cdot \mathrm{g}^{-1}$ ) compared with CT mice (Rf, $234 \pm 10 \mathrm{c}$. $\mathrm{min}^{-1} ; \mathrm{VT} / \mathrm{B}, 19.7 \pm 1.0 \mu \mathrm{l} . \mathrm{g}^{-1} ; \mathrm{Ve}, 4.7 \pm 0.4 \mathrm{ml} . \mathrm{min}^{-1} . \mathrm{g}^{-1}$; unpaired $t$ test, $t_{(25)}=4.580, p<0.001$ for Rf; $t_{(25)}=3.331, p=$ 0.002 for VT/B; $t_{(25)}=3.754, p<0.001$ for $\mathrm{Ve}$ ).

Of the 17 investigated $\mathrm{KO}$ mice, we found only three mice that generated any sighs: one of six at the age range of P5-P6 (16.6\%) and 2 of 11 at the age range of P11-P12 (18\%). By contrast almost all CT littermates sighed in vivo $[n=8$ of $12(66.6 \%)$ at P5-P6; $n=16$ of $16(100 \%)$ at P11-P12; Fig. $1 C, D]$. Of these three KO animals that sighed, sighing was not normal. These mice had a $>10$-fold lower sigh frequency compared with CT mice during both the first $\left(0.02 \pm 0.02\right.$ and $0.25 \pm 0.06 \mathrm{sigh} . \mathrm{min}^{-1}$ for $\mathrm{KO}$ and CT, respectively; unpaired $t$ test, $\left.t_{(16)}=2.412, p<0.05\right)$ and second $\left(0.07 \pm 0.05\right.$ and $0.93 \pm 0.09$ sigh. $\min ^{-1}$ for KO and CT, respectively; unpaired $t$ test, $\left.t_{(25)}=6.993, p<0.001\right)$ postnatal weeks.

As previously described, sighs are always followed by a longer expiratory period (i.e., the postsigh apnea) and thus overall an extended respiratory cycle duration. There was no significant difference between the increase of the respiratory cycle duration of CT mice of the first $(190 \pm 12 \%)$ and the second $(184 \pm 8 \%)$ postnatal weeks $(p=0.68)$. Thus we pooled the values for the 24 CT mice of both age groups that sighed to compare them to the three KO mice of both age groups that sighed. After a sigh, we found no significant difference in the respiratory cycle duration increase between CT $(187 \pm 7 \%)$ and $\mathrm{KO}$ mice $(190 \pm 13 \%$; $p=$ 0.95 , Mann-Whitney $t$ test). 


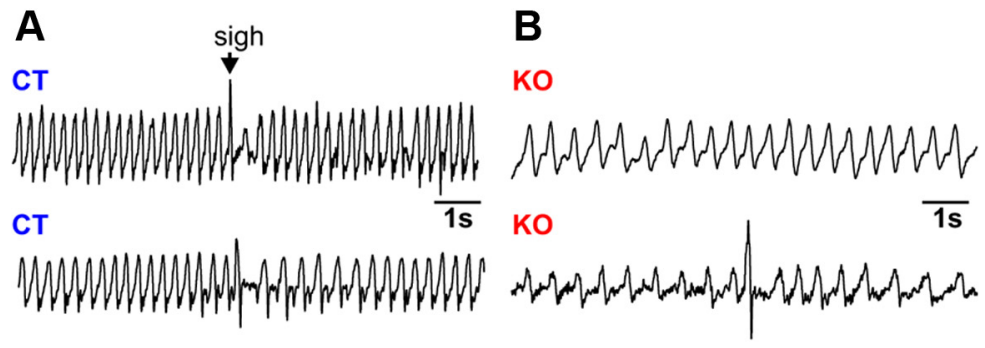

\section{C - First postnatal week}
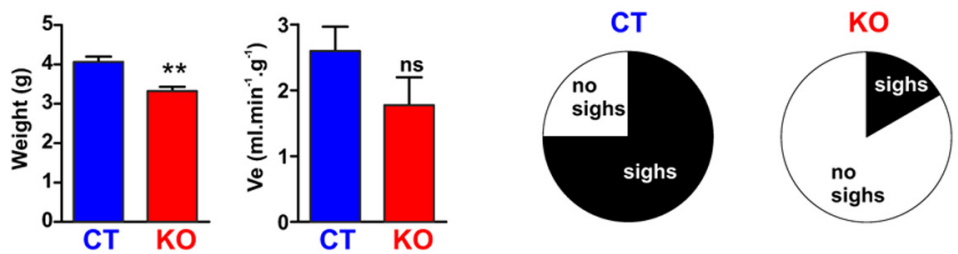

\section{D - Second postnatal week}
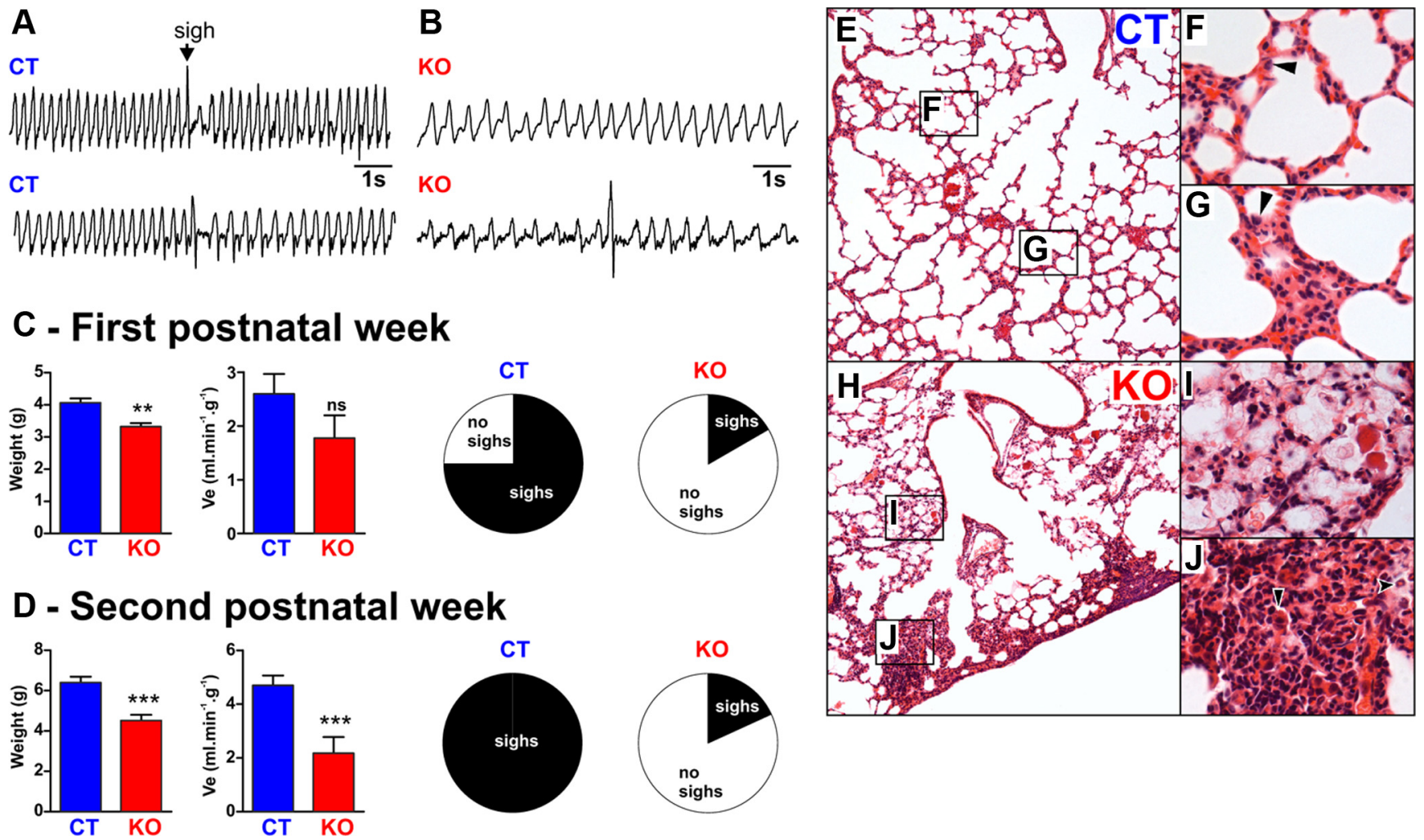

Figure 1. $\quad \boldsymbol{A}, \boldsymbol{B}$, Representative plethysmographic recording of the breathing activity of unanesthetized and unrestrained $\mathrm{CT}(\boldsymbol{A})$ and $\mathrm{KO}(\boldsymbol{B})$ mice during the second postnatal week. Note that $\mathrm{CT}$ mice showed a faster respiratory frequency compared with $\mathrm{KO}$ mice and were periodically generating larger amplitude inspiration, also called augmented breaths or sighs. $C$, From left to right, the charts show the body weight, Ve, and the proportion of $\mathrm{CT}$ and $\mathrm{KO}$ mice that sighed during the first postnatal week. D, Same as C but during the second postnatal week. Note that at both periods KO mice have a lower body weight than (T mice and that only a minority of the K0 mice were able to generate sighs (first postnatal week, $n=12 \mathrm{CT}$ and $n=6 \mathrm{KO}$; second postnatal week, $n=16 \mathrm{CT}$ and $n=11 \mathrm{KO}) . \boldsymbol{E}-\boldsymbol{J}$, Lung sections from $\mathrm{CT}(\boldsymbol{E}-\boldsymbol{G})$ and $\mathrm{KO}(\boldsymbol{H}-\boldsymbol{J})$ mice at P12 stained with hematoxylin and eosin; note that the lungs from the CT mouse have a normal histology, whereas the lungs from the K0 mouse show collapsed alveoli. $F, G$, Higher magnifications of $C T$ mouse lungs show normal lung structure for P12 mouse. $I, J$, In contrast, higher magnifications of K0 mouse lungs show a multifocal distribution of proteinaceous exudates and mixed inflammatory cell infiltrates composed of neutrophils, macrophages, and lymphocytes in the alveolar spaces, consistent with atelectasis (lung histology performed on $3 \mathrm{CT}$ and $3 \mathrm{KO}$ mice). ${ }^{* *} p<0.01,{ }^{* * *} p<0.001$; ns, non-significant.

Histology of lung tissue of $\alpha_{1 \mathrm{~A}}^{-/-}$mice

It is well established for humans that breathing with constant volume leads to atelectasis and decreased lung compliance. Thus, sighing is hypothesized to prevent atelectasis and restore lung compliance (Caro et al., 1960; Ferris and Pollard, 1960; Reynolds, 1962; Bendixen et al., 1964; Bendixen, 1964; Reynolds and Wallander, 1989; Poets et al., 1997; Patroniti et al., 2002; Qureshi et al., 2009; Rival et al., 2011). Based on these human data, we hypothesized that the absence of sighs may be associated with similar pathological changes in lungs of $\mathrm{KO}$ mice compared with CT mice. Air-inflated, intravascular-fixed lungs from 12-d-old CT and $\mathrm{KO}$ mice were prepared, sectioned, and stained with hematoxylin and eosin (Fig. 1E). Qualitative examination showed that all three examined lungs of CT mice have normal lung structure for P12 mice (Fig. $1 E-G$ ). In contrast, the lungs of all three examined $\mathrm{KO}$ mice had multifocal distribution of proteinaceous exudates (Fig. $1 \mathrm{~F}$ ) and mixed inflammatory cell infiltrates composed of neutrophils, macrophages, and lymphocytes (Fig. $1 F)$ in the alveolar spaces, consistent with atelectasis. While we cannot prove that the absence of sighs has caused the atelectasis in $\mathrm{KO}$ mice, our finding is certainly consistent with the long-held hypothesis that the absence of sighs causes atelectasis.

Activity patterns from the preBötC in brainstem slices of $\alpha_{1 \mathrm{~A}}{ }^{-/-}$mice under control conditions

Our laboratory was the first to report that sighs can be generated in the isolated preBötC (Lieske et al., 2000). Sighs are character- ized by their large amplitude and biphasic discharge pattern and a postsigh apnea (Fig. $2 \mathrm{~A}, \mathrm{C}$ ). We hypothesized that the lack of sighs as well as the disturbances in eupneic breathing as observed in vivo may also be reflected at the level of the isolated preBötC. In a first set of in vitro experiments, we recorded and compared the activity from slices of $\mathrm{KO}$ mice and their $\mathrm{CT}$ littermates. We analyzed frequency and duration of fictive eupneic bursts and the number of fictive sighs/10 min generated in the preBötC under control conditions. The data were assessed for two different age groups: (1) slices prepared in the first postnatal week (P5-P7) and (2) slices from mice in the second postnatal week (P9-P14).

The frequency of fictive eupneic bursting did not significantly differ between $\mathrm{KO}$ and CT mice ( $p=0.24$, unpaired $t$ test) in the first postnatal week and was $0.26 \pm 0.04 \mathrm{~Hz}$ in $\mathrm{KO}$ mice $(n=7)$ and $0.36 \pm 0.04 \mathrm{~Hz}$ in CT mice $(n=15)$. In contrast, slices of KO mice $(n=17)$ prepared in the second postnatal week showed a significantly (unpaired $t$ test, $t_{(32)}=3.075, p<0.01$ ) lower eupneic bursting frequency of $0.13 \pm 0.01 \mathrm{~Hz}$ compared with $0.26 \pm$ $0.03 \mathrm{~Hz}$ in slices from CT littermates $(n=17)$. No significant difference in the duration of the fictive eupneic bursts was detected between $\mathrm{KO}$ and CT mice in either the first (CT, $299 \pm 17$ $\mathrm{ms} ; \mathrm{KO}, 341 \pm 44 \mathrm{~ms}$ ) or second postnatal week (CT, $404 \pm 20$ $\mathrm{ms}$; KO, $393 \pm 17 \mathrm{~ms}$ ).

The majority of the 24 examined KO slices did not show any sighs under control conditions (Fig. $2 B$ ), but there were five $\mathrm{KO}$ slices that generated fictive sighs under control conditions (Fig. 2E). There was an age-dependency: during the 

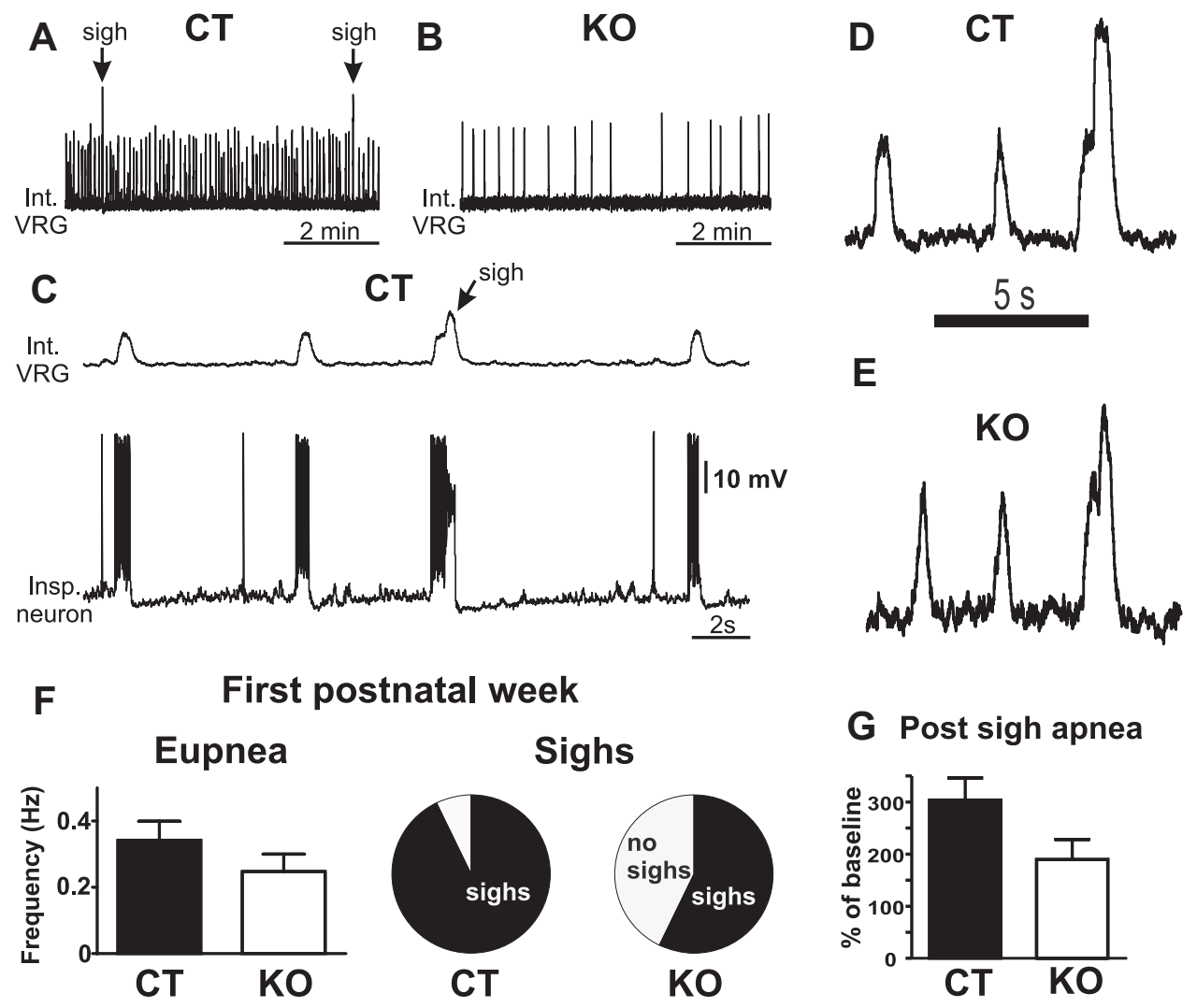

\section{G Post sigh apnea}
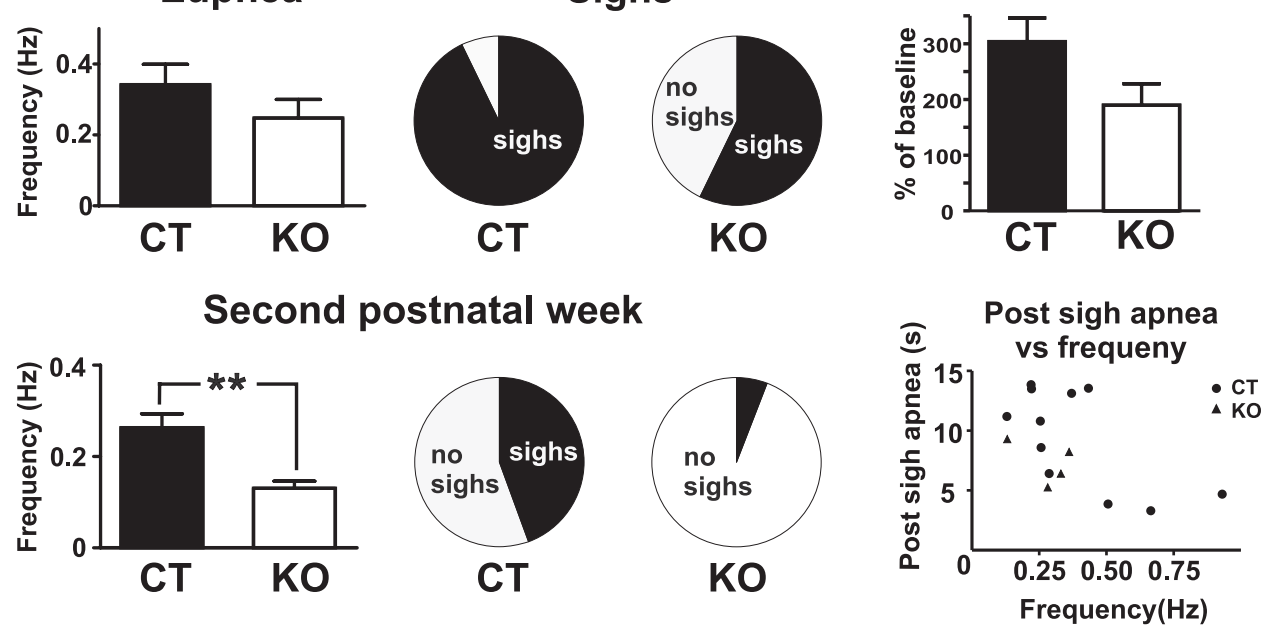

Figure 2. Activity pattern of the isolated preBötC. $\boldsymbol{A}-\boldsymbol{F}$, Typical examples of the activities generated in slices of $\mathrm{CT}(\boldsymbol{A})$ and $\mathrm{KO}(\boldsymbol{B})$ mice. Slices of CT mice showed typically a fast fictive eupneic activity frequency $(\boldsymbol{A}, \boldsymbol{F})$ and were periodically interrupted by biphasic large amplitude burst $(\boldsymbol{A}, \boldsymbol{C}, \boldsymbol{D}$, fictive sighs), while slices of K0 mice had a significantly slower fictive eupneic frequency $(\boldsymbol{B}, \boldsymbol{F})$ and only a minority of the $K 0$ slices were able to generate sighs $(\boldsymbol{E}, \boldsymbol{F})$. $\boldsymbol{C}$, The typical biphasic pattern of a sigh burst on both the neuronal population activity (top trace) and a single inspiratory neuron recorded in whole-cell patch-clamp mode (bottom trace). $\boldsymbol{F}$, Eupnea frequency and sigh proportions in slices of (T and K0 mice from the first (top) and second (bottom) postnatal week. $\boldsymbol{G}$, The postsigh apnea in K0 mice had a tendency to be shorter in K0 mice compared with (T mice (first postnatal week, $n=15$ (T and $n=7 \mathrm{KO}$; second postnatal week, $n=17$ (T and $n=17 \mathrm{KO}$ ). . ${ }^{* *}<<$ 0.01 .

first postnatal week, four of seven (57\%) KO slices generated sighs under control condition, while the majority (93\%) of the 15 CT slices generated sighs (Fig. $2 F$ ). Also note that the four slices of the first postnatal week that generated sighs had a similar postsigh apnea compared with controls $(p=0.143$; Fig. $2 G$ ), which was independent of the baseline frequency of the eupneic activity.

During the second postnatal week, we found only 1 of 17 KO slices (6\%) that generated sighs under control conditions, while 8 of $17(47 \%)$ CT slices generated sighs under control conditions. Next, we characterized in slices that generated sighs the number of fictive sighs per $10 \mathrm{~min}$ bins and compared slices from KO mice with their CT littermates. In the first postnatal week, the number of sighs generated by $\mathrm{KO}$ slices was $0.11 \pm 0.06 \mathrm{sigh} . \mathrm{min}^{-1}$ and $2.26 \pm 0.04 \mathrm{sigh}$. $\min ^{-1}$ in CT slices ( $p=0.14$, unpaired $t$ test).

Since previous data on the sigh generation in slices were obtained from a different strain of mice (CD-1) (Lieske and
Ramirez, 2006), we further tested whether these findings could be extended to the strain used in this study (129/sv). Therefore we bath-applied $\omega$-agatoxin IVA (30 nM) to slices from CT mice (P6-P10) for $30 \mathrm{~min}$. After $30 \mathrm{~min}$, the burst frequency was significantly reduced to $72 \pm 6 \%$ of the burst frequency under control period $(n=8$; repeated-measures ANOVA, $p<0.001)$, while burst amplitude was slightly but significantly increased to $112 \pm 3 \%$ of control (repeated-measures ANOVA, $p<0.01$ ). Sigh frequency was reduced in all CT slices from $0.32 \pm 0.08$ sigh . min $^{-1}$ under control condition to $0.05 \pm 0.04$ sigh. $\mathrm{min}^{-1}$ in the presence of $\omega$-agatoxin IVA (repeated-measures ANOVA, $p<0.001)$. In fact, while all CT slices sighed under control condition, sighs were completely abolished in six of them in the presence of $\omega$-agatoxin IVA. The postsigh apnea lasted $183 \pm$ $13 \%$ of the respiratory cycle duration under control condition and its duration was not affected as long as sighs could be observed during $\omega$-agatoxin IVA application (190 $\pm 14 \%$; paired $t$ test, $p=0.59)$. Overall these results were consistent with those 

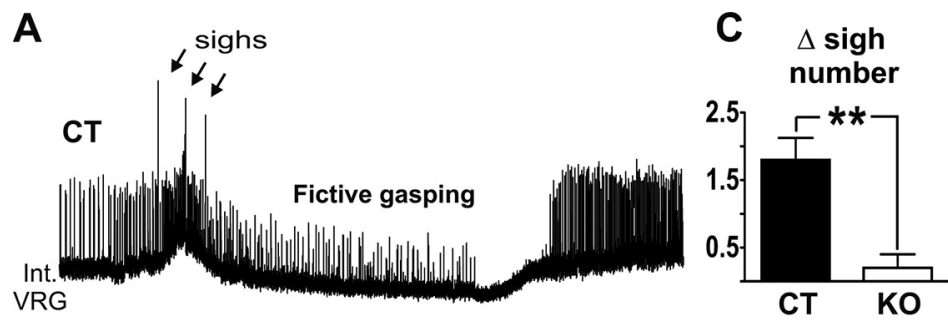

\section{Time To First Burst} (TTFB)
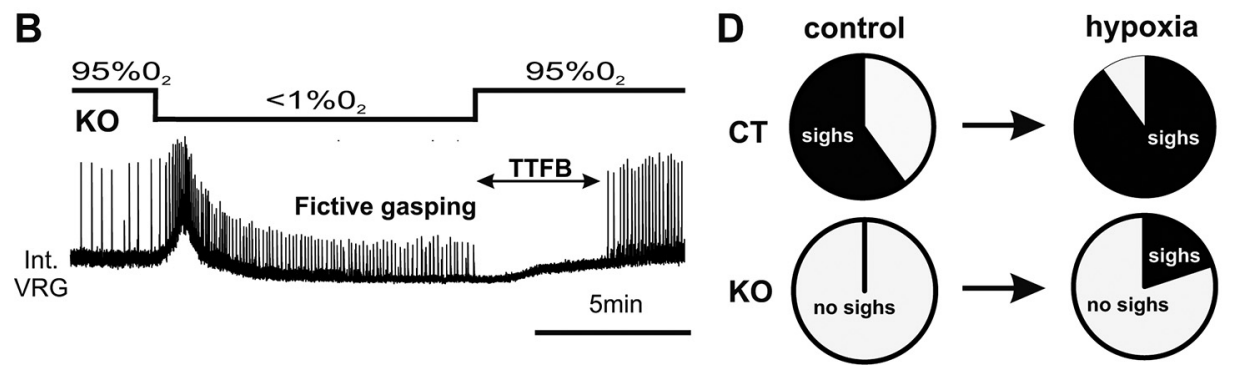

Figure 3. Hypoxic responses in slices of KO $(n=5)$ and $C T(n=9)$ mice. $\boldsymbol{A}, \boldsymbol{B}, \boldsymbol{D}$, Typical network responses of slices from $(\boldsymbol{A})$ a $\mathrm{CT}$ mouse and $(\boldsymbol{B})$ a KO mouse of the second postnatal week after switching to aCSF with $95 \% \mathrm{~N}_{2}$ for 10 min. Note that $(T$ slices generated multiple sighs $(\boldsymbol{A}, \boldsymbol{D}$, arrows) during the early augmentation phase, while most K0 slices did not ( $\boldsymbol{B}, \boldsymbol{D})$. $\boldsymbol{C}$, The difference $(\boldsymbol{\Delta})$ of the number of sighs generated before and during the hypoxic response was statistically higher in CT mice compared with $\mathrm{KO}$ mice. No statistical difference was detected in the amplitude or frequency of fictive gasping. The TTFB was significantly longer in KO compared with CT slices. ${ }^{*} p<0.05$, ${ }^{* *} p<0.01$.

previously obtained in a different mouse strain (Lieske and Ramirez, 2006).

\section{Hypoxic stimulation of the isolated preBötC network to generate sighs}

To test whether we could activate sighs in KO mice, we exposed the slices to hypoxia. As described previously, replacing aCSF equilibrated with $95 \% \mathrm{O}_{2}$ with aCSF equilibrated with $95 \% \mathrm{~N}_{2}$ leads to a biphasic response in the slice preparation with an early augmentation, followed by a late depression phase (Telgkamp and Ramirez, 1999; Lieske et al., 2000; Hill et al., 2011). During the early augmentation phase, the preBötC network reliably generates multiple sighs before it reconfigures into gasping. Only one of five $(20 \%)$ slices obtained from $\mathrm{KO}$ mice during the second postnatal week was able to generate sighs during hypoxia (Fig. $3 B-D)$, while eight of nine ( $89 \%)$ slices from the CT littermates generated on average $2.22 \pm 1.39$ sighs during the augmentation phase (Fig. $3 A, C, D$ ).

Following the augmentation phase (3-4 min after the onset of exposure to $0 \% \mathrm{O}_{2}$ ), the activity of the slices transitioned into the depression phase and generated gasping activity. There was no significant difference in the frequency or amplitude of the fictive gasping activity of KO mice compared with CT littermates (Fig. $3 A, B)$. However upon reoxygenation, $\mathrm{KO}$ slices showed a significantly prolonged time to the first inspiratory burst (TTFB) compared with CT littermates (unpaired $t$ test, $t_{(12)}=2.483, p<0.05$; Fig. 3C).

In vivo recording of breathing activity in anesthetized $\alpha_{1 \mathrm{~A}}{ }^{-1-}$ mice exposed to hypoxic conditions

We used anesthetized freely breathing $\mathrm{CT}$ and $\mathrm{KO}$ mice to characterize sigh generation under control conditions and in response to severe hypoxia in vivo (Fig. 4A, B; see Materials and Methods for details). Under control conditions, 4 of 10 CT mice (40\%) but none of the seven $\mathrm{KO}$ mice (0\%) spontaneously generated sighs (Fig. 4C). Exposure to severe hypoxia for a short-term period (1-2 min) did not reveal any significant difference in the augmentation and depression phases or in the number of sighs and in the TTFB between the two groups (data not shown). In contrast, a longer exposure to severe hypoxia $(3.5 \mathrm{~min})$ led to a significantly reduced numbers of sighs (Mann-Whitney, $p<0.05$ ) and a longer TTFB in the KO group $(n=7,105.78 \pm 43.81 \mathrm{~s})$ compared with the CT group $(n=10,6.63 \pm 2.10 \mathrm{~s}$; Mann-Whitney, $p<0.05$; Fig. $4 F)$. The ratio of mice that generated sighs during the hypoxic exposure was not different (5 of $10 \mathrm{CT}$ mice compared 4 of $7 \mathrm{KO}$ mice; Fig. 4C). However, the mean number of sighs in the CT group was significantly higher $(5.0 \pm 1.38, n=5)$ compared with the KO group $(1.75 \pm 0.75, n=4)$ (MannWhitney, $p<0.05$; Fig. $4 E$ ). Moreover, following the hypoxic exposure, all $10 \mathrm{CT}$ mice recovered breathing to baseline conditions. By contrast, four of seven $\mathrm{KO}$ mice did not recover completely from the severe hypoxia. We therefore subdivided the $\mathrm{KO}$ group. We analyzed the TTFB in one group that survived the hypoxia and a second group that included all $\mathrm{KO}$ mice. Both groups showed a significant longer TTFB when compared with the CT group (ANOVA, $p<0.05$; Fig. $4 F$ ). We conclude that the $\mathrm{KO}$ mice are more sensitive than the CT mice to exposure to severe hypoxia.

Muscarinic stimulation of the isolated preBötC network evokes qualitatively different responses in CT versus $\alpha_{1 \mathrm{~A}}{ }^{-/-}$mice

Activation of muscarinic receptors with oxotremorine has been shown to increase sigh frequency in vitro (Tryba et al., 2008). Here we used bath application of muscarine $(10 \mu \mathrm{M})$, which increased sigh frequency in three of six (50\%) slices prepared from $\mathrm{KO}$ mice during the first postnatal week that were sighing under control condition, while all $10(100 \%)$ slices prepared from CT littermates showed an increase in sigh frequency (Fig. 5A-C). Interestingly, none of the $\mathrm{KO}$ slices taken in the first postnatal week, which did not produce sighs under control, did so in the presence of muscarine ( $n=3$ of 6). In KO slices in the second postnatal week, none showed sigh under control and only one of eight $(12.5 \%)$ slices presented sigh activity after bath application of muscarine. In contrast, all of the five (100\%) CT slices showed a significant increase ( $>100 \%$ increase in the frequency; repeated-measures ANOVA, $p<0.001)$ compared with control conditions (Fig. $5 D$ ). It is noteworthy that, to reveal a potential 
A

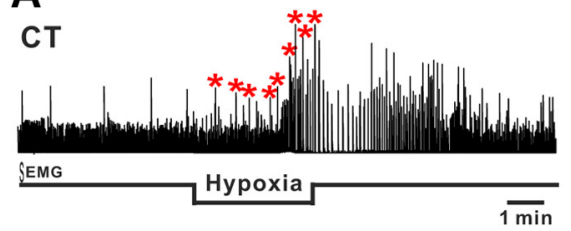

B

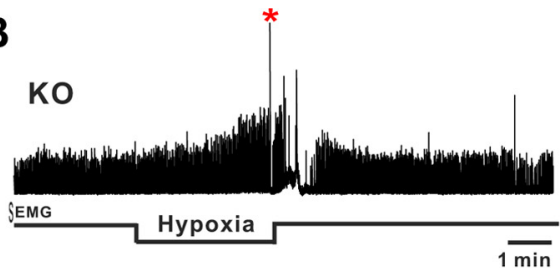

E Number of sighs $\mathbf{F}$
C Control CT

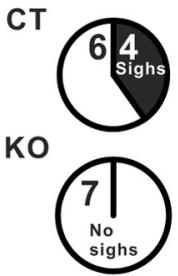

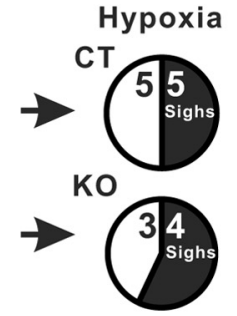

D
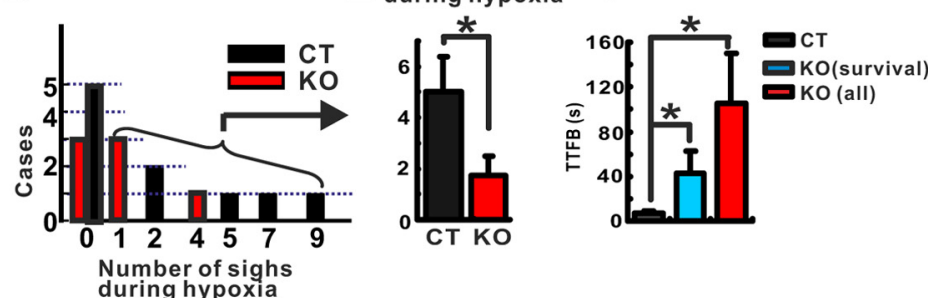

Figure 4. Hypoxic responses in anesthetized freely breathing KO $(n=7)$ and $\mathrm{CT}(n=10)$ mice. $\boldsymbol{A}-\boldsymbol{C}$, Typical responses of $(\boldsymbol{A})$ a $\mathrm{CT}$ mouse and $(\boldsymbol{B})$ a K0 mouse of the second postnatal week after switching to a gas mixture containing $95 \% \mathrm{~N}_{2}$ for $3.5 \mathrm{~min}$. Note that CT mouse generated multiple sighs ( $\boldsymbol{A}$, stars) during the exposure to hypoxia, while the K0 mouse only generated a single sigh (B). No statistical difference was detected in the number of mice that generated sighs before or during hypoxia (C). D, Total number of sighs generated during hypoxia in each case. The number of sighs generated before and during the hypoxic response was statistically higher in CT mice compared with KO mice (E). $\boldsymbol{F}$, The TTFB was significantly longer in KO compared with CT mice. ${ }^{*} p<0.05$.

A

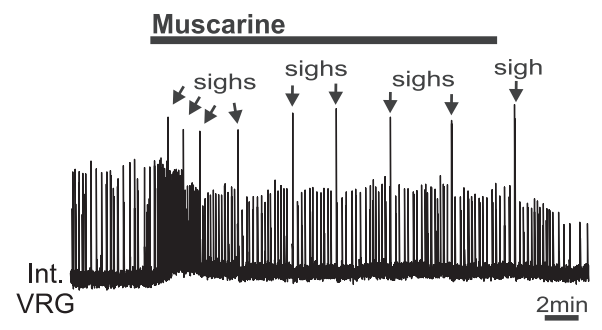

B

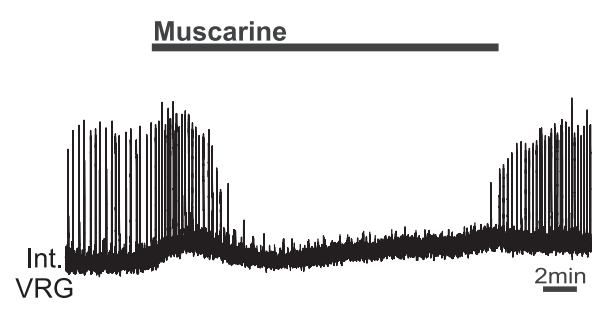

C Sighs

First postnatal week

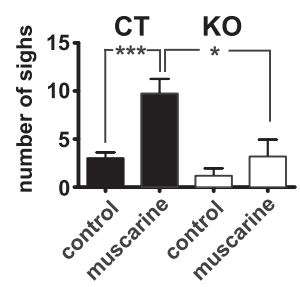

D Sighs

Second postnatal week

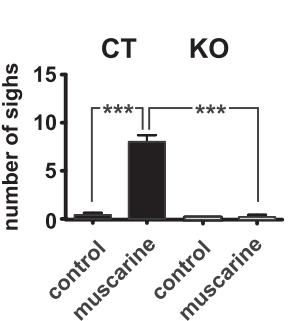

E

Eupnea

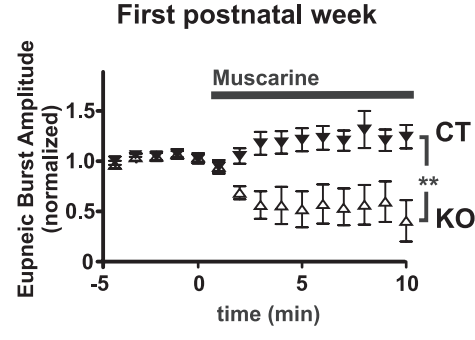

F

Eupnea
Second postnatal week

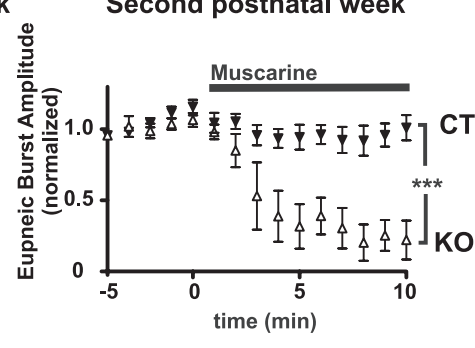

Figure 5. Alterations of the neuromodulation through muscarinic receptors in K0 mice. $\boldsymbol{A}, \boldsymbol{B}$, Typical examples of ( $\boldsymbol{A}$ ) a CT slice showing an increase of sigh frequency (arrows) and ( $\boldsymbol{B}$ ) a K0 mouse without an increase in sighs and a reduction in the amplitude of eupneic bursts. Both examples $(\boldsymbol{A}, \boldsymbol{B})$ are from second postnatal week slices. $\boldsymbol{C}, \boldsymbol{D}$, Note that slices of KO mice obtained in the first postnatal week still show a slight increase in sighs $(\boldsymbol{C}$, while no increase was observed in postnatal week two $(\boldsymbol{D})$. $\boldsymbol{E}, \boldsymbol{F}$, Relative changes in the amplitude of fictive eupneic bursts during exposure to $10 \mu \mathrm{m}$ muscarine of slices obtained from $(\mathrm{T}$ and $\mathrm{KO}$ mice in the first $(\boldsymbol{E})$ and second $(\boldsymbol{F})$ postnatal weeks of life. Note that the amplitude of fictive eupneic bursts was significantly lower in $\mathrm{KO}$ slices compared with CT slices (first postnatal week, $n=10 \mathrm{CT}$ and $n=6 \mathrm{~K} 0$; second postnatal week, $n=5 \mathrm{CT}$ and $n=8 \mathrm{KO}$ ). ${ }^{*} p<0.05,{ }^{* *} p<0.01,{ }^{* * *} p<0.001$.

stimulatory effect on sigh generation, including from slices that did not show sighs under control conditions, these numbers were calculated from all slices (the ones that did and the ones that did not produce sighs under control).

Interestingly, bath application of $10 \mu \mathrm{M}$ muscarine led also to a qualitatively different response of the eupneic activity in $\mathrm{KO}$ slices (Fig. 5B) compared with CT slices (Fig. 5A) (Zanella et al., 2007; Tryba et al., 2008). CT slices in the first postnatal week $(n=$ $10)$ and second postnatal week $(n=5)$ showed a typical biphasic response (Fig. 5A). After bath application of muscarine, the amplitude of the eupneic activity slightly increased in slices of the first postnatal week and showed no significant difference in slices prepared in the second postnatal week. In contrast, bath application of muscarine in KO slices profoundly decreased the eupneic bursting activity in slices prepared from the first (repeatedmeasures ANOVA, $p<0.01$ ) and second postnatal weeks (repeated-measures ANOVA, $p<0.001$; Fig. $5 B, E, F$ ).

Pharmacological inhibition of N-type calcium channels To test whether the preBötC network following genetic ablation of the P/Q-type channels becomes more dependent on the 
N-type $\left(\mathrm{Ca}_{\mathrm{v}} 2.2\right)$ calcium channels, we used a pharmacological approach.

In brainstem slices from CT mice, pharmacological blockade of the N-type calcium channel by conotoxin GVIA $(0.5-$ $1 \mu \mathrm{M})$ led to a slight decrease in burst frequency (Fig. 6A) in preparation obtained from postnatal week 1 (Fig. $6 C ; n=10$ ) and postnatal week 2 (Fig. $6 D ; n=4$ ). By contrast, in slices from KO mice, bath application of conotoxin GVIA completely abolished all bursting activity in both postnatal week 1 (Fig. $6 C ; n=5$ ) and postnatal week 2 (Fig. $6 B, D ; n=7$ ), indicating that the $\mathrm{KO}$ but not the $\mathrm{CT}$ mice depend entirely on $\mathrm{N}$-type calcium channels to generate respiratory activities $(p<0.001)$.

As previously described, sighing activity persists under blockade of N-type calcium channel by conotoxin GVIA (Lieske and Ramirez, 2006). Here in all slices from CT mice that sighed, the sighing activity was preserved. Interestingly the postsigh apnea was significantly reduced from $233 \pm 42 \%$ of the respiratory cycle duration under control condition to $152 \pm$ $34 \%$ of the respiratory cycle duration in the presence of conotoxin GVIA (paired $t$ test, $t_{(4)}=3.551, p=0.02$ ). This finding was consistent with a previous report (Lieske and Ramirez, 2006) and thus extends this mechanism to another mouse strain. Unfortunately none of the slices from $\mathrm{KO}$ mice tested in this set of experiments sighed under control conditions. Therefore we were not able to test the effect of conotoxin GVIA on sighs in KO slices.

\section{Basic cellular firing properties of preBötC neurons of $\alpha_{1 \mathrm{~A}}{ }^{-/-}$ mice}

It has been reported that the $\mathrm{P} / \mathrm{Q}$-type channels are a determinant of the firing properties in some neuronal subtypes of the cerebellum (Llinás and Sugimori, 1980; Mark et al., 2011) and the inferior olive (Choi et al., 2010). To test whether the preBötC neurons of $\mathrm{KO}$ mice have alterations in their firing properties, we recorded from inspiratory neurons of slices prepared from $\mathrm{KO}$ $(n=8)$ and CT $(n=15)$ mice. Inspiratory preBötC neurons were identified by their synchronous discharge pattern with population activity from contralateral preBötC (Fig. 7B). We detected no significant difference in any of the analyzed properties (unpaired $t$ test, resting potential, $p=0.79$; action potentials/burst, $p=0.098$; drive potential, $p=0.713$ ) (Fig. 7C-E).

\section{Alterations in the synaptic properties of $\alpha_{1 \mathrm{~A}}{ }^{-/-}$mice}

We next investigated potential differences in synaptic transmission between $\mathrm{KO}$ and CT mice. As described in detail in Materials and Methods, EPSPs recorded in inspiratory neurons were electrically evoked from the contralateral preBötC (Fig. $8 \mathrm{~A}$ ). The amplitude of the EPSPs evoked in inspiratory neurons of $\mathrm{KO}$ $(n=4)$ mice was significantly smaller than that of the EPSPs of CT mice $\left(n=9\right.$, unpaired $t$ test, $t_{(11)}=2.306, p<0.05$; Fig. $\left.8 C\right)$. EPSPs could be completely abolished with conotoxin GVIA in KO mice $(n=3)$, while it led to only a $30 \%$ reduction of the amplitude in CT mice $\left(n=3\right.$, unpaired $t$ test, $t_{(4)}=4.96, p<0.01$; Fig. $8 D, E)$. No significant correlation was observed between the age of the animals and the amplitude of evoked EPSPs from either $\mathrm{KO}(n=4)$ or CT slices $(n=8)$ (Fig. $8 B)$.

Neuroanatomy of the preBötC area of $\alpha_{1 \mathrm{~A}}{ }^{-/-}$mice

To determine whether $\mathrm{KO}$ mice showed obvious qualitative differences in the anatomy and cellular organization in the brainstem, we first performed a set of histology experiments to assess brainstem gross morphology and neuronal composition in the preBötC. No apparent differences in the gross morphology of the brainstem were observed in either the first or second postnatal week as assessed by Nissl stain between $\mathrm{CT}$ and $\mathrm{KO}$ mice in transverse sections (Fig. 9A-D). Schematic diagram of the brainstem in transverse view is shown in Figure $9 E$ to better visualize the neuroanatomical location of major nuclei (including preBötC) and cranial nerves. To further investigate whether the composition of glutamatergic neurons within the preBötC area was different between KO mice and CT littermates, we used in situ hybridization to assess the expression and distribution of Vglut2 mRNA. The expression of Vglut2 mRNA in the brainstem did not show an overall change in the KO mice compared with CT for both stages evaluated (Fig. 9F-I'). To further assess whether the number of glutamatergic neurons was altered specifically in the preBötC area, we quantified the number of Vglut2-positive neurons within the preBötC area and we observed no difference between $\mathrm{KO}$ and CT mice at both age groups (Fig. 9J; P5, $p=0.24$; P13, $p=0.28$ ), suggesting (but not proving) that the observed decrease in synaptic transmission is not due to a decrease in the number of glutamatergic neurons. We also compared NK1R expression in $\mathrm{CT}$ and $\mathrm{KO}$ medulla at both first and second postnatal weeks. Transverse sections through the medulla at comparable levels of the preBötC revealed a compact, well defined arrangement and high density of NK1R-immunopositive cells in the first and second postnatal weeks of age (Fig. $9 K, K^{\prime}, M, M^{\prime}$ ). We also did not find a change in cell number or reduced NK1R expression, as DAPI+ nuclear staining revealed no change in the number of cell nuclei per preBötC (Fig. $9 K^{\prime}-N, O$; P5, $p=0.69$; P13, $p=0.79)$, and the NK1R + fluorescence intensity seemed not to 

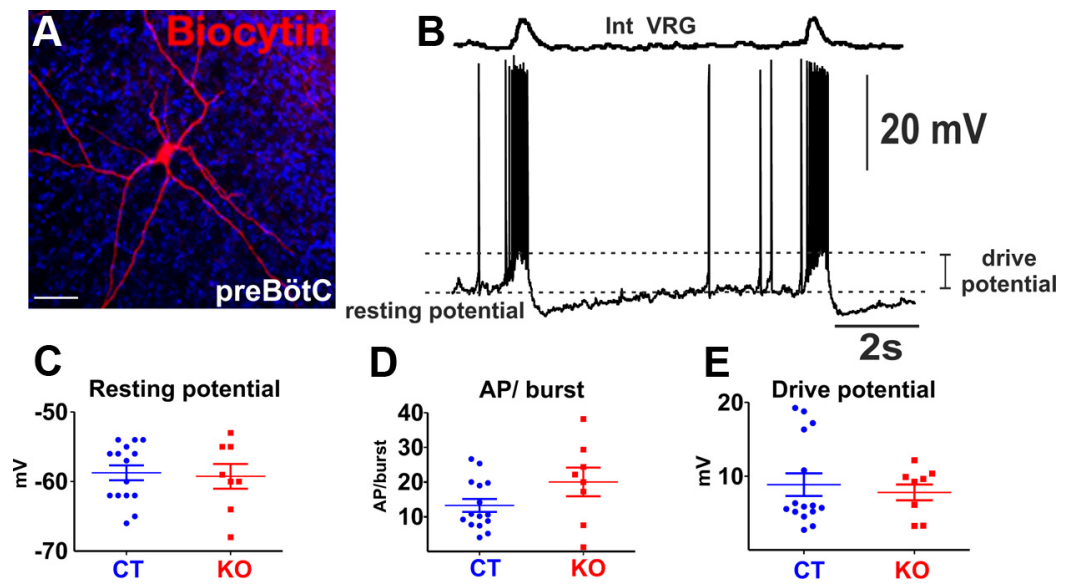

Figure 7. Electrophysiological properties of inspiratory neurons from KO $(n=8)$ and $\mathrm{CT}(n=15)$ mice recorded from slices at rest. $A, B$, Stain of a typical inspiratory neuron as identified by its phasic discharge pattern $(\boldsymbol{A})$ with the population recording of the contralateral VRG $(\boldsymbol{B}) . \boldsymbol{C}-\boldsymbol{E}$, Neurons of the preBötC of $\mathrm{KO}$ and $(\mathrm{T}$ mice did not show differences in their intrinsic properties, including the resting membrane potential $(\boldsymbol{C})$, the number of action potentials (AP) per inspiratory burst $(\boldsymbol{D})$, and the drive potential measured during an inspiratory burst $(\boldsymbol{E})$.
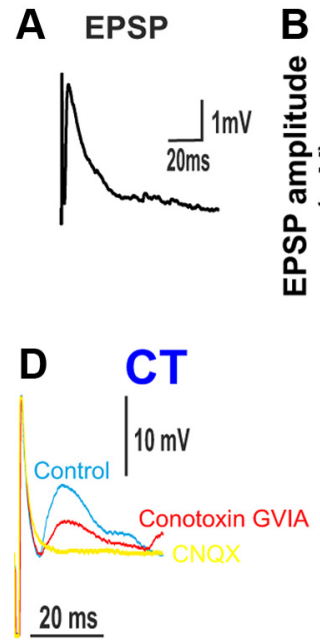
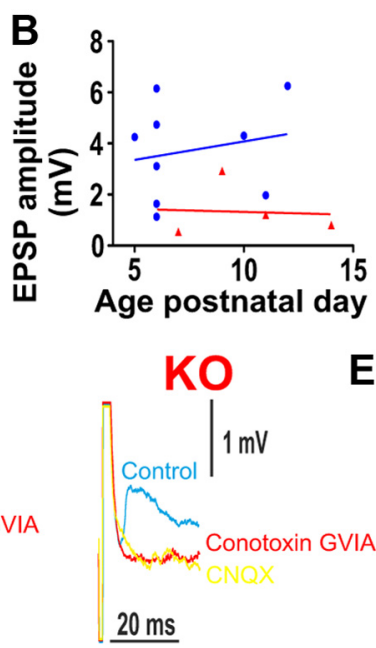

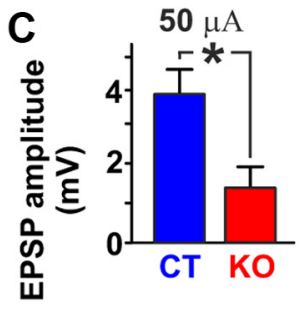

E
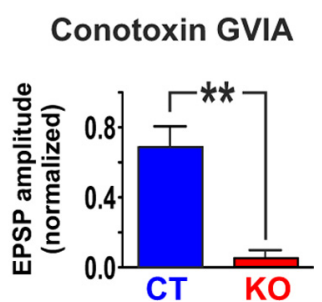

Figure 8. Alterations in the synaptic transmission in $\mathrm{KO}$ mice. $\boldsymbol{A}$, Whole-cell recording of an inspiratory neuron showing an EPSP evoked by electrical stimulation of the contralateral preBötC. $B$, No obvious differences in the amplitude of EPSPs could be detected due to the age of the animal in KO or CT mice. $C$, The amplitudes of EPSPs of KO $(n=4)$ mice were significantly smaller at $50 \mu \mathrm{A}$ $\left(p^{*}<0.05\right)$ compared with CT $(n=8)$ mice. $\boldsymbol{D}, \boldsymbol{E}, \operatorname{In} \mathrm{CT}(n=3)$ mice, EPSP amplitude fell by $30 \%$ when $\mathrm{N}$-type calcium channels were blocked. In KO $(n=3)$ mice, EPSP amplitude fell almost to zero when N-type calcium channels were blocked. ${ }^{*} p<0.05$, ${ }^{* *} p<0.01$.

be qualitatively altered at this stage as determined by measuring fluorescence intensity (quantification not shown). To address whether cell death in the preBötC area could cause the breathing abnormalities we observed in the KOs in the second postnatal week, we immunostained for active-caspase-3 (AC3), a marker for apoptosis, but found no AC3-positive cells within the preBötC area of KO and CT littermates (data not shown).

Overall, these results suggest that the gross anatomical morphology and neuronal composition of the brainstem is largely unaltered in $\mathrm{KO}$ compared with CT mice.

\section{Discussion}

Mutations in voltage-gated ion channels have been implicated in numerous neurological disorders. Yet the clinical phenotypes are potentially complicated by compensatory genetic, neuromodulatory, and/or developmental changes. Here, we investigated the consequences of ablating the gene encoding the pore-forming $\alpha$-1a subunit of $\mathrm{Ca}_{\mathrm{v}} 2.1$, which in homozygous-null mice results in ataxia, motor dysfunction, and ultimately death within the first 3-4 postnatal weeks (Jun et al., 1999). The consequences of conditional loss of function of $\mathrm{Ca}_{\mathrm{v}} 2.1$ calcium currents has been studied in several brain regions, including the cerebellum (Jun et al., 1999; Iwasaki et al., 2000; Mark et al., 2011), thalamus and neocortex (Iwasaki et al., 2000), and brainstem (Choi et al., 2010). A study using a conditional $\mathrm{Ca}_{\mathrm{v}} 2.1$ $\mathrm{KO}$ in cerebellar Purkinje cells recapitulated most of the phenotype of the constitutive null KO (Mark et al., 2011). However, these mice survive into adulthood, suggesting that other brain regions determine early lethality in the constitutive $\mathrm{Ca}_{\mathrm{v}} 2.1 \mathrm{KO}$ background.

Here we characterized the effects of the loss of $\mathrm{Ca}_{\mathrm{v}} 2.1$ on the neuronal control of breathing. KO mice showed increasingly severe breathing disturbances as they entered the second postnatal week, with only a few producing spontaneous sighs. Consistent with the presumed role of sighs in the prevention of atelectasis and maintaining lung compliance (Caro et al., 1960; Ferris and Pollard, 1960; Bendixen et al., 1964; Bendixen, 1964; Poets et al., 1997; Patroniti et al., 2002; Qureshi et al., 2009; Rival et al., 2011), postmortem histology showed obvious anatomical signs of atelectasis among $\mathrm{KO}$ mice. The mixed inflammatory cell infiltrate in these lungs is consistent with pneumonia occurring by P12. Our data suggest, but do not prove, that sighs are important for maintaining normal functional residual capacity (FRC), which is necessary for clearing debris and pathogens from the lungs. We hypothesize that poor lung ventilation associated with the absence of sighs and reduced FRC causes atelectasis-related pathologies and contributes to early morbidity in $\mathrm{Ca}_{\mathrm{v}} 2.1 \mathrm{KO}$ mice.

Loss of sighs and reduced eupneic frequency in KO animals were likely due to central mechanisms involving the preBötC. Consistent with in vivo plethysmography, fictive eupneic burst frequency was reduced in preBötC slices from KO mice. Moreover, only a minority of KO slices generated fictive sighs. These findings are reminiscent of pharmacological studies demonstrating that acute blockade of $\mathrm{Ca}_{\mathrm{v}} 2.1$ in wild-type slices abolished fictive sighs and slowed eupneic bursts (Lieske and Ramirez, 2006). Based on these studies, we did not expect that a subset of KO mice was capable of generating sighs. In CT slices, sigh-promoting stimuli, such as hypoxic exposure or muscarine, increased sigh frequency (Lieske et al., 2000; Tryba et al., 2008). Thus, sighs are activated by a combination of presynaptic calcium currents with $\mathrm{N}$-type calcium channels contributing $30 \%$ and P/Q-type channels contributing 70\% to the presynaptic current. Without $\mathrm{P} / \mathrm{Q}$-type calcium channels, the remaining $\mathrm{N}$-type calcium current is sufficient to generate slow eupneic 

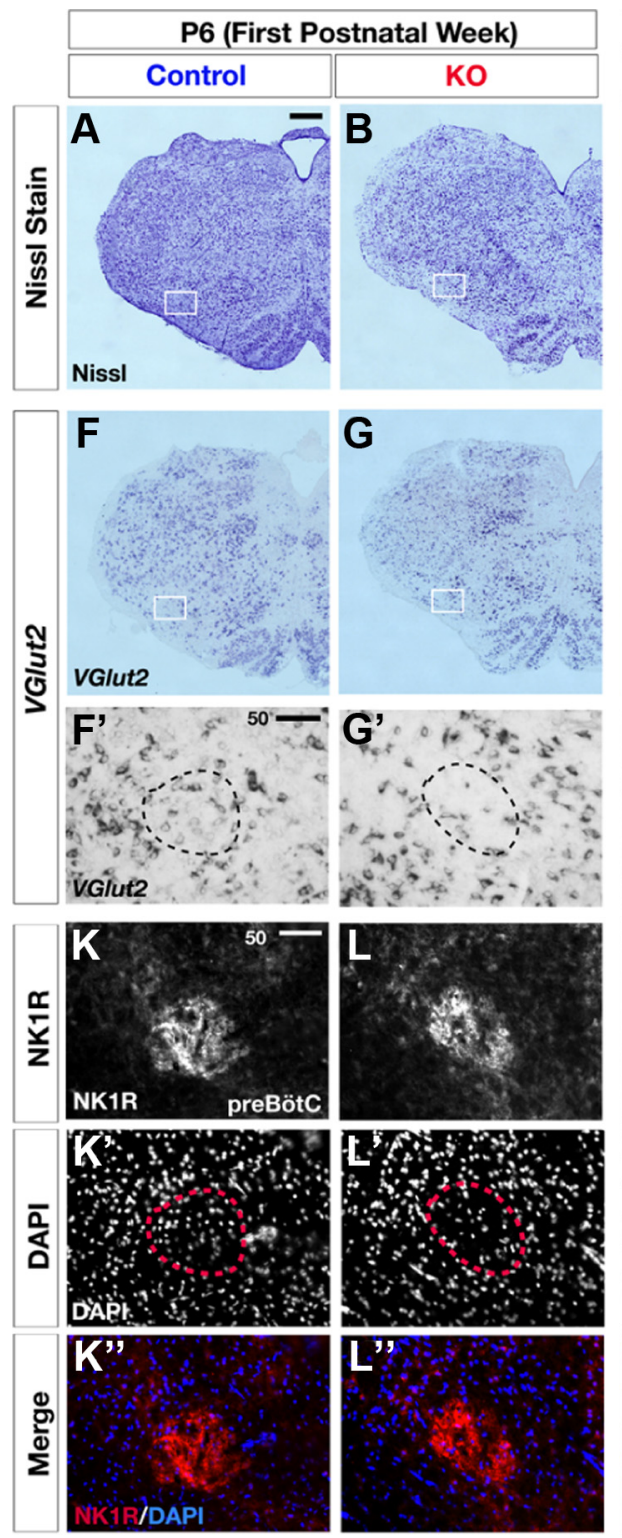
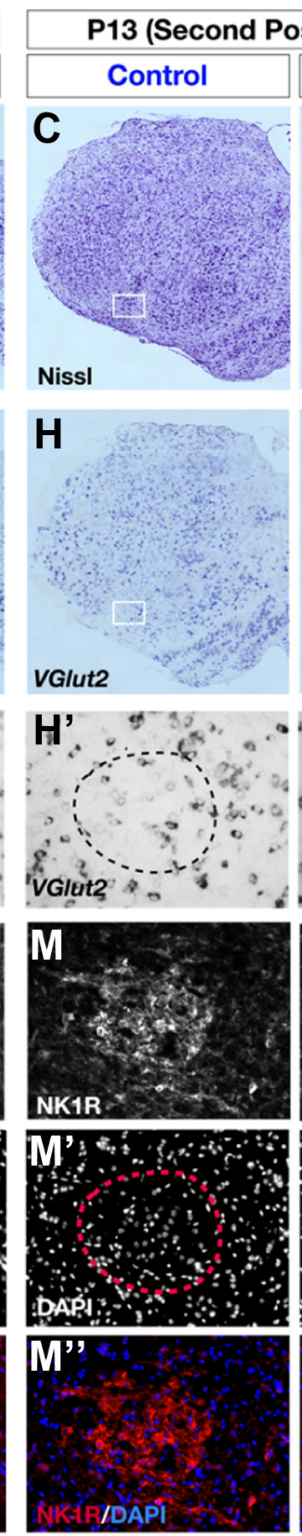

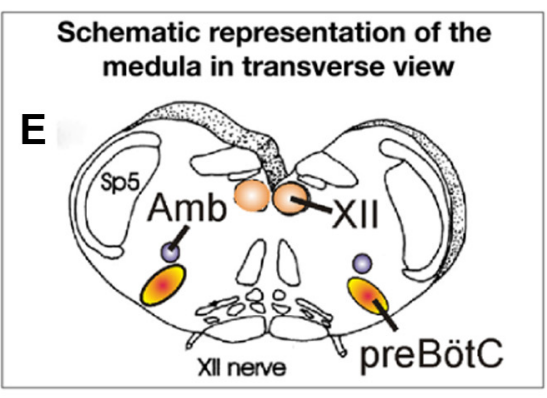

$\mathbf{J}$

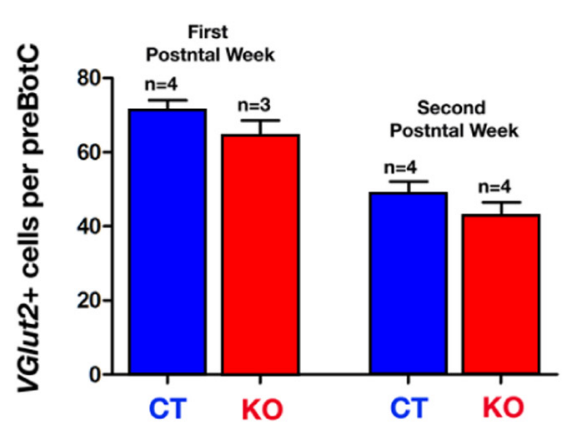

0
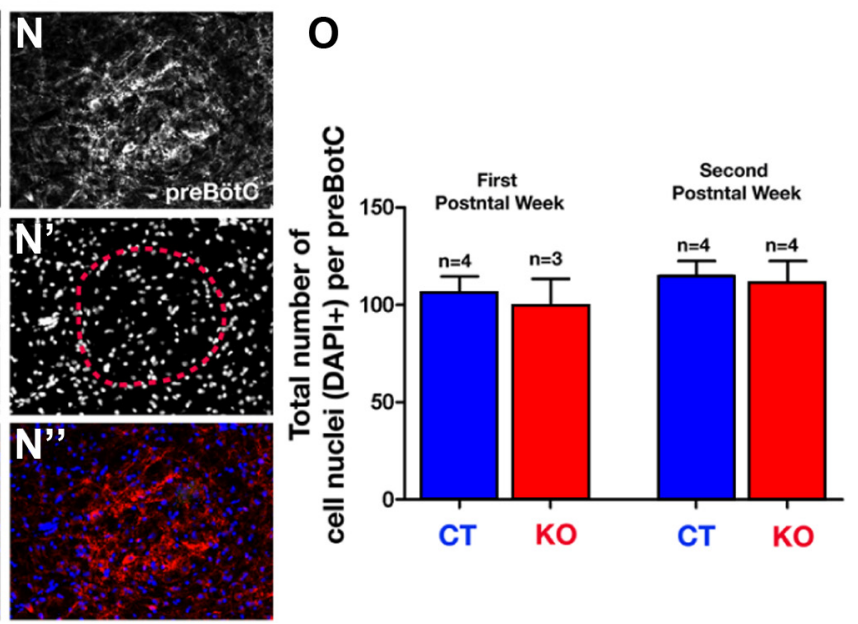

Figure 9. Histological analysis showing normal brainstem gross morphology in KO mice. $\boldsymbol{A}-\boldsymbol{D}$, Representative images of a Nissl-stained histological transverse hemisections through the brainstem at comparable levels of preBötC at P6 $(\boldsymbol{A}, \boldsymbol{B})$ and $\mathrm{P} 13(\boldsymbol{C}, \boldsymbol{D})$, revealing no gross morphological defects of the medulla in $\mathrm{KO}$ mice $(\boldsymbol{B}, \boldsymbol{D})$ compared with $C$ T mice $(\boldsymbol{A}, \boldsymbol{C})$ (white frame indicates preBötC area; $(\mathrm{T}, n=4 ; \mathrm{K} 0, n=4$ for each age group). $\boldsymbol{E}$, Schematic representation of a transverse section through the brainstem illustrating the area of the preBötC and other brainstem nuclei. XII, hypoglossus nucleus; Amb, ambiguus nucleus; $S p 5$, spinal trigeminal nucleus. $\boldsymbol{F}-\boldsymbol{I}^{\prime}, \mathbf{I}$ situ hybridization for $\operatorname{Vglut2}$ on $\mathrm{P} 6(\boldsymbol{F}, \boldsymbol{H})$ and $\mathrm{P} 13(\boldsymbol{G}, \boldsymbol{I})$ transverse hemisections reveals normal expression and distribution of Vglut2 mRNA levels in glutamatergic neurons of the preBötC area (white frames show the magnified views in insets $\left.\boldsymbol{F}^{\prime} \boldsymbol{- I}\right)$ in $\mathrm{KO}\left(\boldsymbol{G}, \boldsymbol{G}^{\prime}, \boldsymbol{I}, \boldsymbol{I}\right)$ compared with $\left(\mathrm{C}\right.$ mice $\left(\boldsymbol{F}, \boldsymbol{F}^{\prime}, \boldsymbol{H}, \boldsymbol{H}^{\prime}\right)$ at both age groups. J, Quantitative analysis of Vglut2-positive neurons within the preBötC area reveals no change in K0 mice (white bars) compared with (T mice (black bars). $\boldsymbol{K}-\boldsymbol{K}^{\prime \prime}$, Immunofluorescence for NK1R within the preBötC area $(\boldsymbol{K}-\boldsymbol{N})$ and DAPI to label cell nuclei $\left(\boldsymbol{K}^{\prime}-\boldsymbol{N}^{\prime}\right)$, and merge images $\left(\boldsymbol{K}^{\prime \prime}-\boldsymbol{N}^{\prime \prime}\right)$, showing that structural integrity of NK1R-positive cells is maintained in the preBötC area of P6 and P13 K0 mice $\left(\boldsymbol{L}, \boldsymbol{L}^{\prime \prime}, \boldsymbol{N}, \boldsymbol{N}^{\prime \prime}\right)$ compared with P6 and P13, respectively, control mice $\left(\boldsymbol{K}, \boldsymbol{K}^{\prime \prime}, \boldsymbol{M}, \boldsymbol{M}\right)$. $\mathbf{0}$, Histogram showing the number of cells (DAPI+) within the preBötC is not quantitatively changed both at P6 and P13 in $\mathrm{KO}$ and (T mice. Number (n) of mice indicated in the graph. Scale bars: $\boldsymbol{A}, 200 \mu \mathrm{m}$ (for $\boldsymbol{A}-\boldsymbol{I}) ; \boldsymbol{F}^{\prime}, \boldsymbol{K}, 50 \mu \mathrm{m}$ (for $\boldsymbol{F}^{\prime}-\boldsymbol{N}^{\prime \prime}$ ).

activity, but insufficient to trigger sighs in the majority of cases. By contrast, without N-type calcium channels, sighs are still generated because $60 \%$ of the presynaptic current is mediated by P/Q-type calcium channels. We hypothesize that the synaptic currents mediated by N-type and P/Q-type currents activate an inward current that boosts the respiratory network to generate a sigh burst. Other studies have suggested that sigh generation involves the persistent sodium current (INaP), because blocking this current abolishes sighs but not eupneic activity (Peña et al., 2004). Moreover, oxotremorine, which activates sighs, can initiate large amplitude bursts mediated by the INaP (Tryba et al., 2008). By contrast, eupneic activity seems to rely on calcium- activated nonspecific cationic $\left(\mathrm{I}_{\mathrm{CAN}}\right)$ currents as its boosting mechanism (Del Negro et al., 2005; Ramirez et al., 2011). These currents may have a lower threshold to be activated. Hence eupneic activity is still maintained when synaptic mechanisms are only mediated by the N-type calcium current, such as is the case in $\mathrm{KO}$ mice. Thus, we propose that eupneic and sigh activities depend on different intrinsic "boost" mechanisms: INaP for eupneic activies and $\mathrm{I}_{\text {CAN }}$ currents for sigh activities. These boost mechanisms are synaptically activated and may have different thresholds, hence explaining why loss of $\mathrm{P} / \mathrm{Q}$ type calcium channels eliminates mostly sighs, while eupneic activity persists, albeit at lower frequencies. 
Many synapses rely on more than one $\mathrm{Ca}^{2+}$-channel subtype (Leenders et al., 2002; Urbano et al., 2002; Cao et al., 2005) and mutual compensatory mechanisms or functional redundancy between $\mathrm{Ca}^{2+}$-channel subtypes is well known (Qian and Noebels, 2000; Takahashi et al., 2004a,b; Kaja et al., 2006). In the present study, we demonstrated functional redundancy using the specific blocker of $\mathrm{Ca}_{\mathrm{v}} 2.2 \omega$-conotoxin GVIA (Olivera et al., 1994; Kulak et al., 2001), which reduced fictive respiratory frequency during the first and second postnatal weeks in controls, but abolished fictive respiratory activity (including sighs) in KO slices. Thus, respiratory rhythm generation became entirely dependent on $\mathrm{Ca}_{\mathrm{v}} 2.2$ following $\mathrm{Ca}_{\mathrm{v}} 2.1$ ablation.

Loss of $\mathrm{Ca}_{\mathrm{v}} 2.1$ reduced glutamatergic transmission within the preBötC. Our pharmacological experiments confirmed that $\mathrm{Ca}_{\mathrm{v}} 2.2$ accounts for $\sim 30 \%$ of excitatory synaptic transmission (Lieske and Ramirez, 2006). In KO slices, EPSP amplitudes were reduced, and further pharmacological blockade of $\mathrm{Ca}_{\mathrm{v}} 2.2$ abolished EPSPs. Thus, synaptic transmission, which normally depends on both $\mathrm{Ca}_{\mathrm{v}} 2.1$ and $\mathrm{Ca}_{\mathrm{v}} 2.2$, becomes solely dependent on $\mathrm{Ca}_{\mathrm{v}} 2.2$ in $\mathrm{Ca}_{\mathrm{v}} 2.1$-null mice.

Why do these mutant mice survive initially and die later? An increased expression of $\mathrm{Ca}_{\mathrm{v}} 2.2$ early in development could allow the initial survival of $\mathrm{KO}$ mice, and a subsequent developmental downregulation of $\mathrm{Ca}_{\mathrm{v}} 2.2$ could result in death. Indeed, an $\omega$-conotoxin GVIA binding study of the developing rodent brain reveals initially an increased and subsequently a reduced binding to $\mathrm{Ca}_{\mathrm{v}} 2.2$ within the medulla (Filloux et al., 1994). Notably, this reduction is most evident within the ventral medulla, even though intense labeling is maintained in the solitary tract nucleus into adulthood (Takemura et al., 1987, 1988). This finding is corroborated by studies in a variety of systems that indicate that postnatal synaptic transmission developmentally switches from $\mathrm{Ca}_{\mathrm{v}} 2.2$ to $\mathrm{Ca}_{\mathrm{v}} 2.1$ dependency (Filloux et al., 1994; Iwasaki and Takahashi, 1998; Rosato Siri and Uchitel, 1999; Iwasaki et al., 2000).

However, the situation may be different for the respiratory network. We found no evidence for a developmental change in EPSPs between the first and the second postnatal weeks, nor for the ability of $\omega$-conotoxin GVIA to reduce fictive respiratory frequency. Moreover, injection of $\omega$-conotoxin GVIA into the preBötC of adult cats transiently blocks respiratory activity (Ramirez et al., 1998b). These observations suggest that in the wild-type respiratory circuit, dependency on $\mathrm{Ca}_{\mathrm{v}} 2.2$ is maintained into adulthood.

Alternatively, the delayed morbidity could be explained by a developmental change of other types of inward and outward currents (Nerbonne and Gurney, 1989; Xia and Haddad, 1994a,b; Gao and Ziskind-Conhaim, 1998; Brocard et al., 2006), or by breathing disturbances that could cause intermittent periods of hypoxia, which in turn alter sodium currents and neuronal excitability (Xia et al., 2000; Zhao et al., 2005).

Moreover, distinct developmental profiles may imbue different regions with the differential properties of the different ionchannel subtypes. For some central synapses, calcium influx triggers synaptic release more efficiently through $\mathrm{Ca}_{\mathrm{v}} 2.1$ than through $\mathrm{Ca}_{\mathrm{v}} 2.2$ (Wu et al., 1999; Hefft and Jonas, 2005). For neocortical inhibitory inputs from parvalbumin-containing fastspiking interneurons to pyramidal cells, $\mathrm{Ca}_{\mathrm{v}} 2.1$ may be beneficial at synapses with high probability of release and precise timing of neurotransmission. Other studies in hippocampus indicate that $\mathrm{Ca}_{\mathrm{v}} 2.1$ is associated with synapses that exhibit synaptic depression, while $\mathrm{Ca}_{\mathrm{v}} 2.2$ is predominantly associated with synapses that facilitate (Ali and Nelson, 2006). Possibly, the immature respira- tory network requires a mixture of $\mathrm{Ca}_{\mathrm{v}} 2.2$ and $\mathrm{Ca}_{\mathrm{v}} 2.1$ to generate sighs and fully functional respiratory activity.

Another possible factor contributing to the $\mathrm{Ca}_{\mathrm{v}} 2.1 \mathrm{KO}$ phenotype may be altered neuromodulation. The $\alpha_{1 \mathrm{a}}$ subunit colocalizes with cholinergic neurons (Plomp et al., 2000), and here we found a dramatic difference in the respiratory response to muscarine between $\mathrm{KO}$ and CT slices. While muscarine reduced the respiratory frequency in CT slices and augmented sighs (Zanella et al., 2007; Tryba et al., 2008), it completely abolished fictive eupnea in KO slices. Muscarine activates several receptors and can modulate both $\mathrm{Ca}_{\mathrm{v}} 2.2$ and $\mathrm{Ca}_{\mathrm{v}} 2.1$ (Endoh, 2007). The suppression of respiratory activity in $\mathrm{KO}$ mice may not be too surprising. In this mutant network, synaptic transmission is presynaptically impaired because it relies only on $30 \%$ of the calcium current, which is mediated by $\mathrm{Ca}_{\mathrm{v}} 2.2$. A neuromodulator that further inhibits $\mathrm{Ca}_{\mathrm{v}} 2.2$, such as muscarine (Bernheim et al., 1992; Allen and Brown, 1993; Catterall, 1998; Perez-Rosello et al., 2005), would completely abolish network interactions, leading to the cessation of respiratory rhythm generation. This altered modulatory response could have detrimental consequences in states characterized by increased cholinergic drive, such as wakefulness and rapid-eye-movement sleep (Horner, 1996; Doi and Ramirez, 2008; Saper et al., 2010).

In conclusion, our study indicates that genetic ablation of $\mathrm{Ca}_{\mathrm{v}} 2.1$ has multiple consequences at many levels of integration from the cellular to the behavioral level. We specifically hypothesize that a loss of sighs coupled with inefficient breathing leads to lung atelectasis, lung inflammation, and ultimately death. Conceptually, our study suggests that synaptic functions relying on more than one ion channel may continue to generate a behavioral output even if one of the ion channels is mutated. However, this mutated network activity is severely compromised, as it may succumb to an altered modulatory drive, or fail to generate the full spectrum of its possible activity patterns. Moreover, the loss of a single ion-channel subtype must be considered within the context of developmental changes of other ion channels. As a result, the same mutation may differentially affect neuronal, modulatory, and behavioral functions at different stages of development. Thus, while it is often assumed that compensatory mechanisms, such as the upregulation or downregulation of other channels, may significantly contribute to the complexity of a given phenotype, the present study indicates that developmental interrelationships and redundancy of different ion channels, receptors, and modulators play at least equally important roles in the complexity emerging from an apparently simple ionchannel mutation.

\section{References}

Ali AB, Nelson C (2006) Distinct Ca2 + channels mediate transmitter release at excitatory synapses displaying different dynamic properties in rat neocortex. Cereb Cortex 16:386-393. Medline

Allen TG, Brown DA (1993) M2 muscarinic receptor-mediated inhibition of the $\mathrm{Ca} 2+$ current in rat magnocellular cholinergic basal forebrain neurones. J Physiol 466:173-189. Medline

Bedogni F, Hodge RD, Elsen GE, Nelson BR, Daza RA, Beyer RP, Bammler TK, Rubenstein JL, Hevner RF (2010) Tbr1 regulates regional and laminar identity of postmitotic neurons in developing neocortex. Proc Natl Acad Sci U S A 107:13129-13134. CrossRef Medline

Bendixen HH (1964) Atelectasis and shunting. Anesthesiology 25:595-596. CrossRef Medline

Bendixen HH, Smith GM, Mead J (1964) Pattern of ventilation in young adults. J Appl Physiol 19:195-198. Medline

Bernheim L, Mathie A, Hille B (1992) Characterization of muscarinic receptor subtypes inhibiting $\mathrm{Ca} 2+$ current and $\mathrm{M}$ current in rat sympathetic neurons. Proc Natl Acad Sci U S A 89:9544-9548. CrossRef Medline 
Brocard F, Verdier D, Arsenault I, Lund JP, Kolta A (2006) Emergence of intrinsic bursting in trigeminal sensory neurons parallels the acquisition of mastication in weanling rats. J Neurophysiol 96:2410-2424. CrossRef Medline

Cao CM, Xia Q, Gao Q, Chen M, Wong TM (2005) Calcium-activated potassium channel triggers cardioprotection of ischemic preconditioning. J Pharmacol Exp Ther 312:644-650. Medline

Caro CG, Butler J, Dubois AB (1960) Some effects of restriction of chest cage expansion on pulmonary function in man: an experimental study. J Clin Invest 39:573-583. CrossRef Medline

Catterall WA (1998) Structure and function of neuronal Ca2+ channels and their role in neurotransmitter release. Cell Calcium 24:307-323. CrossRef Medline

Choi S, Yu E, Kim D, Urbano FJ, Makarenko V, Shin HS, Llinás RR (2010) Subthreshold membrane potential oscillations in inferior olive neurons are dynamically regulated by P/Q- and T-type calcium channels: a study in mutant mice. J Physiol 588:3031-3043. CrossRef Medline

De Marco García NV, Karayannis T, Fishell G (2011) Neuronal activity is required for the development of specific cortical interneuron subtypes. Nature 472:351-355. CrossRef Medline

Del Negro CA, Morgado-Valle C, Hayes JA, Mackay DD, Pace RW, Crowder EA, Feldman JL (2005) Sodium and calcium currentmediated pacemaker neurons and respiratory rhythm generation. J Neurosci 25:446-453. CrossRef Medline

Doi A, Ramirez JM (2008) Neuromodulation and the orchestration of the respiratory rhythm. Respir Physiol Neurobiol 164:96-104. CrossRef Medline

Dunlap K, Luebke JI, Turner TJ (1995) Exocytotic Ca2 + channels in mammalian central neurons. Trends Neurosci 18:89-98. CrossRef Medline

Endoh T (2007) Muscarinic M2 receptor inhibition of calcium current in rat nucleus tractus solitarius. Neuroreport 18:1141-1145. CrossRef Medline

Ferris BG Jr, Pollard DS (1960) Effect of deep and quiet breathing on pulmonary compliance in man. J Clin Invest 39:143-149. CrossRef Medline

Filloux F, Schapper A, Naisbitt SR, Olivera BM, McIntosh JM (1994) Complex patterns of [125I] omega-conotoxin GVIA binding site expression during postnatal rat brain development. Brain Res Dev Brain Res 78:131136. Medline

Gao BX, Ziskind-Conhaim L (1998) Development of ionic currents underlying changes in action potential waveforms in rat spinal motoneurons. J Neurophysiol 80:3047-3061. Medline

Glasscock E, Qian J, Yoo JW, Noebels JL (2007) Masking epilepsy by combining two epilepsy genes. Nat Neurosci 10:1554-1558. CrossRef Medline

Gourfinkel-An I, Baulac S, Nabbout R, Ruberg M, Baulac M, Brice A, LeGuern E (2004) Monogenic idiopathic epilepsies. Lancet Neurol 3:209218. CrossRef Medline

Hall BJ, Ghosh A (2008) Regulation of AMPA receptor recruitment at developing synapses. Trends Neurosci 31:82-89. CrossRef Medline

Hayes JA, Wang X, Del Negro CA (2012) Cumulative lesioning of respiratory interneurons disrupts and precludes motor rhythms in vitro. Proc Natl Acad Sci U S A 109:8286-8291. CrossRef Medline

Hefft S, Jonas P (2005) Asynchronous GABA release generates long-lasting inhibition at a hippocampal interneuron-principal neuron synapse. Nat Neurosci 8:1319-1328. CrossRef Medline

Hevner RF, Shi L, Justice N, Hsueh Y, Sheng M, Smiga S, Bulfone A, Goffinet AM, Campagnoni AT, Rubenstein JL (2001) Tbr1 regulates differentiation of the preplate and layer 6. Neuron 29:353-366. CrossRef Medline

Hill AA, Garcia AJ 3rd, Zanella S, Upadhyaya R, Ramirez JM (2011) Graded reductions in oxygenation evoke graded reconfiguration of the isolated respiratory network. J Neurophysiol 105:625-639. CrossRef Medline

Hirtz JJ, Boesen M, Braun N, Deitmer JW, Kramer F, Lohr C, Müller B, Nothwang HG, Striessnig J, Löhrke S, Friauf E (2011) $\mathrm{Ca}_{\mathrm{v}} 1.3$ calcium channels are required for normal development of the auditory brainstem. J Neurosci 31:8280-8294. CrossRef Medline

Horner RL (1996) Motor control of the pharyngeal musculature and implications for the pathogenesis of obstructive sleep apnea. Sleep 19:827-853. Medline

Iwasaki S, Takahashi T (1998) Developmental changes in calcium channel types mediating synaptic transmission in rat auditory brainstem. J Physiol 509:419-423. CrossRef Medline

Iwasaki S, Momiyama A, Uchitel OD, Takahashi T (2000) Developmental changes in calcium channel types mediating central synaptic transmission. J Neurosci 20:59-65. Medline

Jansen LA, Peugh LD, Roden WH, Ojemann JG (2010) Impaired maturation of cortical GABA(A) receptor expression in pediatric epilepsy. Epilepsia 51:1456-1467. CrossRef Medline

Jun K, Piedras-Rentería ES, Smith SM, Wheeler DB, Lee SB, Lee TG, Chin H, Adams ME, Scheller RH, Tsien RW, Shin HS (1999) Ablation of P/Qtype $\mathrm{Ca}(2+)$ channel currents, altered synaptic transmission, and progressive ataxia in mice lacking the alpha(1A)-subunit. Proc Natl Acad Sci U S A 96:15245-15250. CrossRef Medline

Kaja S, Van de Ven RC, Ferrari MD, Frants RR, Van den Maagdenberg AM, Plomp JJ (2006) Compensatory contribution of Cav2.3 channels to acetylcholine release at the neuromuscular junction of tottering mice. J Neurophysiol 95:2698-2704. Medline

Kulak JM, McIntosh JM, Yoshikami D, Olivera BM (2001) Nicotine-evoked transmitter release from synaptosomes: functional association of specific presynaptic acetylcholine receptors and voltage-gated calcium channels. J Neurochem 77:1581-1589. CrossRef Medline

Leenders AG, van den Maagdenberg AM, Lopes da Silva FH, Sheng ZH, Molenaar PC, Ghijsen WE (2002) Neurotransmitter release from tottering mice nerve terminals with reduced expression of mutated P- and Q-type Ca2+-channels. Eur J Neurosci 15:13-18. CrossRef Medline

Lieske SP, Ramirez JM (2006) Pattern-specific synaptic mechanisms in a multifunctional network. I. Effects of alterations in synapse strength. J Neurophysiol 95:1323-1333. CrossRef Medline

Lieske SP, Thoby-Brisson M, Telgkamp P, Ramirez JM (2000) Reconfiguration of the neural network controlling multiple breathing patterns: eupnea, sighs and gasps [see comment]. Nat Neurosci 3:600-607. CrossRef Medline

Llinás R, Sugimori M (1980) Electrophysiological properties of in vitro Purkinje cell dendrites in mammalian cerebellar slices. J Physiol 305:197-213. Medline

Mark MD, Maejima T, Kuckelsberg D, Yoo JW, Hyde RA, Shah V, Gutierrez D, Moreno RL, Kruse W, Noebels JL, Herlitze S (2011) Delayed postnatal loss of P/Q-type calcium channels recapitulates the absence epilepsy, dyskinesia, and ataxia phenotypes of genomic CACNA1A mutations. J Neurosci 31:4311-4326. CrossRef Medline

Mintz IM (1994) Block of Ca channels in rat central neurons by the spider toxin $\omega$-Aga-IIIA. J Neurosci 14:2844-2853. Medline

Mintz IM, Venema VJ, Swiderek KM, Lee TD, Bean BP, Adams ME (1992) P-type calcium channels blocked by the spider toxin omega-Aga-IVA. Nature 355:827-829. CrossRef Medline

Möhler H (2006) GABA(A) receptor diversity and pharmacology. Cell Tissue Res 326:505-516. CrossRef Medline

Moreno RL, Ribera AB (2010) Developmental regulation of subtypespecific motor neuron excitability. Ann N Y Acad Sci 1198:201-207. CrossRef Medline

Nerbonne JM, Gurney AM (1989) Development of excitable membrane properties in mammalian sympathetic neurons. J Neurosci 9:3272-3286. Medline

Neychev VK, Fan X, Mitev VI, Hess EJ, Jinnah HA (2008) The basal ganglia and cerebellum interact in the expression of dystonic movement. Brain 131:2499-2509. CrossRef Medline

Olivera BM, Miljanich GP, Ramachandran J, Adams ME (1994) Calcium channel diversity and neurotransmitter release: the omega-conotoxins and omega-agatoxins. Annu Rev Biochem 63:823-867. CrossRef Medline

Ophoff RA, Terwindt GM, Vergouwe MN, van Eijk R, Oefner PJ, Hoffman SM, Lamerdin JE, Mohrenweiser HW, Bulman DE, Ferrari M, Haan J, Lindhout D, van Ommen GJ, Hofker MH, Ferrari MD, Frants RR (1996) Familial hemiplegic migraine and episodic ataxia type- 2 are caused by mutations in the Ca2+ channel gene CACNL1A4. Cell 87:543-552. CrossRef Medline

Patroniti N, Foti G, Cortinovis B, Maggioni E, Bigatello LM, Cereda M, Pesenti A (2002) Sigh improves gas exchange and lung volume in patients with acute respiratory distress syndrome undergoing pressure support ventilation. Anesthesiology 96:788-794. CrossRef Medline

Peña F, Parkis MA, Tryba AK, Ramirez JM (2004) Differential contribution of pacemaker properties to the generation of respiratory rhythms during normoxia and hypoxia. Neuron 43:105-117. CrossRef Medline

Perez-Rosello T, Figueroa A, Salgado H, Vilchis C, Tecuapetla F, Guzman JN, Galarraga E, Bargas J (2005) Cholinergic control of firing pattern and neurotransmission in rat neostriatal projection neurons: role of CaV2.1 
and CaV2.2 Ca2+ channels. J Neurophysiol 93:2507-2519. CrossRef Medline

Pietrobon D (2010) CaV2.1 channelopathies. Pflugers Arch 460:375-393. CrossRef Medline

Plomp JJ, Vergouwe MN, Van den Maagdenberg AM, Ferrari MD, Frants RR, Molenaar PC (2000) Abnormal transmitter release at neuromuscular junctions of mice carrying the tottering alpha( $1 \mathrm{~A}) \mathrm{Ca}(2+)$ channel mutation. Brain 123:463-471. CrossRef Medline

Poets CF, Rau GA, Neuber K, Gappa M, Seidenberg J (1997) Determinants of lung volume in spontaneously breathing preterm infants. Am J Respir Crit Care Med 155:649-653. Medline

Qian J, Noebels JL (2000) Presynaptic $\mathrm{Ca}^{2+}$ influx at a mouse central synapse with $\mathrm{Ca}^{2+}$ channel subunit mutations. J Neurosci 20:163-170. Medline

Qureshi M, Khalil M, Kwiatkowski K, Alvaro RE (2009) Morphology of sighs and their role in the control of breathing in preterm infants, term infants and adults. Neonatology 96:43-49. CrossRef Medline

Ramirez JM, Quellmalz UJ, Wilken B, Richter DW (1998a) The hypoxic response of neurones within the in vitro mammalian respiratory network. J Physiol 507:571-582. CrossRef Medline

Ramirez JM, Schwarzacher SW, Pierrefiche O, Olivera BM, Richter DW (1998b) Selective lesioning of the cat pre-Botzinger complex in vivo eliminates breathing but not gasping. J Physiol 507:895-907. CrossRef Medline

Ramirez JM, Koch H, Garcia AJ 3rd, Doi A, Zanella S (2011) The role of spiking and bursting pacemakers in the neuronal control of breathing. J Biol Phys 37:241-261. CrossRef Medline

Reynolds MR (1962) Allergy in children: simplified management. Arch Pediatr 79:137-150. Medline

Reynolds MS, Wallander KA (1989) Use of surfactant in the prevention and treatment of neonatal respiratory distress syndrome. Clin Pharm 8:559-576. Medline

Rival G, Patry C, Floret N, Navellou JC, Belle E, Capellier G (2011) Prone position and recruitment manoeuvre: the combined effect improves oxygenation. Crit Care 15:R125. CrossRef Medline

Rosato Siri MD, Uchitel OD (1999) Calcium channels coupled to neurotransmitter release at neonatal rat neuromuscular junctions. J Physiol 514:533-540. CrossRef Medline

Ruangkittisakul A, Schwarzacher SW, Secchia L, Ma Y, Bobocea N, Poon BY, Funk GD, Ballanyi K (2008) Generation of eupnea and sighs by a spatiochemically organized inspiratory network. J Neurosci 28:2447-2458. CrossRef Medline

Saper CB, Fuller PM, Pedersen NP, Lu J, Scammell TE (2010) Sleep state switching. Neuron 68:1023-1042. CrossRef Medline

Smith JC, Ellenberger HH, Ballanyi K, Richter DW, Feldman JL (1991) PreBotzinger complex: a brainstem region that may generate respiratory rhythm in mammals. Science 254:726-729. CrossRef Medline

Takahashi E, Ino M, Miyamoto N, Nagasu T (2004a) Expression analysis of $\mathrm{P} / \mathrm{Q}$-type Ca2 + channel alpha 1A subunit mRNA in olfactory mitral cell in N-type Ca2 + channel alpha 1B subunit gene-deficient mice. Neurosci Lett 359:37-40. CrossRef Medline

Takahashi E, Ino M, Miyamoto N, Nagasu T (2004b) Increased expression of $\mathrm{P} / \mathrm{Q}$-type $\mathrm{Ca} 2+$ channel alpha1A subunit mRNA in cerebellum of $\mathrm{N}$-type Ca2 + channel alpha1B subunit gene-deficient mice. Brain Res Mol Brain Res 124:79-87. Medline

Takemura M, Fukui H, Wada H (1987) Different localization of receptors for omega-conotoxin and nitrendipine in rat brain. Biochem Biophys Res Commun 149:982-988. CrossRef Medline

Takemura M, Kiyama H, Fukui H, Tohyama M, Wada H (1988) Autoradiographic visualization in rat brain of receptors for omega-conotoxin GVIA, a newly discovered calcium antagonist. Brain Res 451:386-389. CrossRef Medline

Tan W, Janczewski WA, Yang P, Shao XM, Callaway EM, Feldman JL (2008) Silencing preBotzinger complex somatostatin-expressing neurons induces persistent apnea in awake rat. Nat Neurosci 11:538-540. CrossRef Medline

Telgkamp P, Ramirez JM (1999) Differential responses of respiratory nuclei to anoxia in rhythmic brain stem slices of mice. J Neurophysiol 82:21632170. Medline

Tryba AK, Peña F, Lieske SP, Viemari JC, Thoby-Brisson M, Ramirez JM (2008) Differential modulation of neural network and pacemaker activity underlying eupnea and sigh-breathing activities. J Neurophysiol 99: 2114-2125. CrossRef Medline

Tse YC, Bagot RC, Hutter JA, Wong AS, Wong TP (2011) Modulation of synaptic plasticity by stress hormone associates with plastic alteration of synaptic NMDA receptor in the adult hippocampus. PLoS One 6:e27215. CrossRef Medline

Turner TJ, Adams ME, Dunlap K (1992) Calcium channels coupled to glutamate release identified by omega-Aga-IVA. Science 258:310-313. CrossRef Medline

Urbano FJ, Rosato-Siri MD, Uchitel OD (2002) Calcium channels involved in neurotransmitter release at adult, neonatal and P/Q-type deficient neuromuscular junctions (Review). Mol Membr Biol 19:293-300. CrossRef Medline

Wenninger JM, Pan LG, Klum L, Leekley T, Bastastic J, Hodges MR, Feroah TR, Davis S, Forster HV (2004) Large lesions in the pre-Botzinger complex area eliminate eupneic respiratory rhythm in awake goats. J Appl Physiol 97:1629-1636. CrossRef Medline

Wheeler DB, Randall A, Tsien RW (1994) Roles of N-type and Q-type Ca2+ channels in supporting hippocampal synaptic transmission. Science 264: 107-111. CrossRef Medline

Wu LG, Westenbroek RE, Borst JG, Catterall WA, Sakmann B (1999) Calcium channel types with distinct presynaptic localization couple differentially to transmitter release in single calyx-type synapses. J Neurosci 19: 726-736. Medline

Xia Y, Haddad GG (1994a) Voltage-sensitive $\mathrm{Na}+$ channels increase in number in newborn rat brain after in utero hypoxia. Brain Res 635: 339-344. CrossRef Medline

Xia Y, Haddad GG (1994b) Postnatal development of voltage-sensitive $\mathrm{Na}+$ channels in rat brain. J Comp Neurol 345:279-287. CrossRef Medline

Xia Y, Fung ML, O'Reilly JP, Haddad GG (2000) Increased neuronal excitability after long-term $\mathrm{O}(2)$ deprivation is mediated mainly by sodium channels. Brain Res Mol Brain Res 76:211-219. Medline

Zanella S, Viemari JC, Hilaire G (2007) Muscarinic receptors and alpha2adrenoceptors interact to modulate the respiratory rhythm in mouse neonates. Respir Physiol Neurobiol 157:215-225. CrossRef Medline

Zhang Y, Vilaythong AP, Yoshor D, Noebels JL (2004) Elevated thalamic low-voltage-activated currents precede the onset of absence epilepsy in the SNAP25-deficient mouse mutant coloboma. J Neurosci 24: 5239-5248. CrossRef Medline

Zhao P, Xue J, Gu XQ, Haddad GG, Xia Y (2005) Intermittent hypoxia modulates $\mathrm{Na}+$ channel expression in developing mouse brain. Int $\mathrm{J}$ Dev Neurosci 23:327-333. CrossRef Medline

Zhuchenko O, Bailey J, Bonnen P, Ashizawa T, Stockton DW, Amos C, Dobyns WB, Subramony SH, Zoghbi HY, Lee CC (1997) Autosomal dominant cerebellar ataxia (SCA6) associated with small polyglutamine expansions in the alpha $1 \mathrm{~A}$-voltage-dependent calcium channel. Nat Genet 15:62-69. CrossRef Medline 